\title{
THERMAL EXPANSION AND PHASE INVERSION OF RARE-EARTH OXIDES
}

By Stephan Stecura and William J. Campbell

* * * * * * * * * * report of investigations 5847

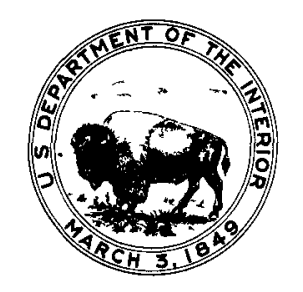

UNITED STATES DEPARTMENT OF THE INTERIOR

Stewart L. Udall, Secretary

BUREAU OF MINES

Marling J. Ankeny, Director 
This publication has been cataloged as follows:

\section{Stecura, Stephan}

Thermal expansion and phase inversion of rare-earth oxides, by Stephan Stecura and William J. Campbell. [Washington] U. S. Dept. of the Interior, Bureau of Mines [1961]

ii, 47 p. illus., tables. $27 \mathrm{~cm}$. (U. S. Bureau of Mines. Report of inve stigations, 5847)

Bibliography: p. $46-47$

1. Rare-earth oxides-Thermal properties, I. Campbell, William J joint author. II. Title. III. Title: Phase inversion of rareearth oxides. (Series)

[TN23.U7 no. 5847] 622.06173

U. S. Dept. of the Int. Library 


\section{DISCLAIMER}

This report was prepared as an account of work sponsored by an agency of the United States Government. Neither the United States Government nor any agency Thereof, nor any of their employees, makes any warranty, express or implied, or assumes any legal liability or responsibility for the accuracy, completeness, or usefulness of any information, apparatus, product, or process disclosed, or represents that its use would not infringe privately owned rights. Reference herein to any specific commercial product, process, or service by trade name, trademark, manufacturer, or otherwise does not necessarily constitute or imply its endorsement, recommendation, or favoring by the United States Government or any agency thereof. The views and opinions of authors expressed herein do not necessarily state or reflect those of the United States Government or any agency thereof. 


\section{DISCLAIMER}

Portions of this document may be illegible in electronic image products. Images are produced from the best available original document. 


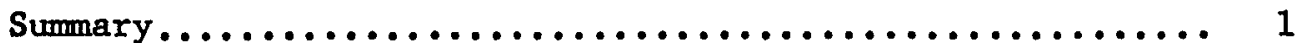

Introduction................................ 2

Instrumentation................................. 3

Temperature measurement....................... 6

Sample preparation........................... 7

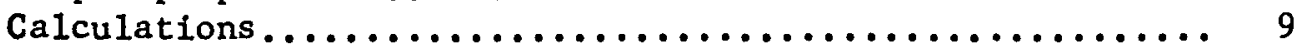

Accuracy of expansion measurements .................. 10

Experiment results and discussion.................. 11

Bibliography ............................... 46

\section{ILLUSTRATIONS}

Fig.

1. High-temperature $\mathrm{X}$-ray diffractometer............ 4

2. Cutaway view of furnace showing heater and thermocouple locations....................... 5

3. Precision of thermal expansion measurements........ 12

4. Thermal expansion of scandium sesquioxide......... 13

5. Thermal expansion of yttrium sesquioxide.......... 16

6. Thermal expansion of lanthanum sesquioxide......... 18

7. Thermal expansion of cerium dioxide.............. 20

8. Thermal expansion of praseodymium oxide $\left(\operatorname{Pr}_{6} \mathrm{O}_{21}\right) \ldots 22$

9. Thermal expansion of neodymium sesquioxide......... 25

10. Thermal expansion of samarium sesquioxide.......... 27

11. Thermal expansion of europium sesquioxide......... 30

12. Thermal expansion of gadolinium sesquioxide....... 31

13. Thermal expansion of dysprosium sesquioxide........ 34

14. Thermal expansion of holmium sesquioxide.......... 36

15. Thermal expansion of erbium sesquioxide.......... 37

16. Thermal expansion of thulium sesquioxide.......... 39

17. Thermal expansion of ytterbium sesquioxide......... 41

18. Thermal expansion of lutetium sesquioxide......... 43 


\section{TABLES}

Page

1. Determination of thermal gradients in oxidizing atmosphere furnace....................... 7

2. Optical spectrographic analyses of rare-earth oxides. 8

3. Calculated errors for linear expansion measurements using diffractometer techniques............... 11

4. Thermal expansion of scandium oxide................ 14

5. Thermal expansion of yttrium oxide............... 15

6. Therma1 expansion of lanthanum oxide.............. 17

7. Powder X-ray diffraction data for lanthanum oxide at

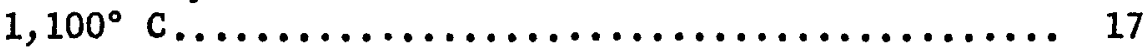

8. Thermal expansion of cerium dioxide............... 19

9. Thermal expansion of praseodymium oxide............. 21

10. Powder $X$-ray diffraction data for praseodymium oxide

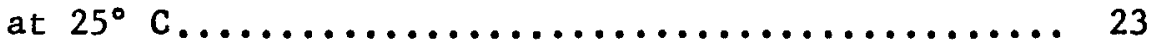

11. Powder X-ray diffraction data for praseodymium oxide

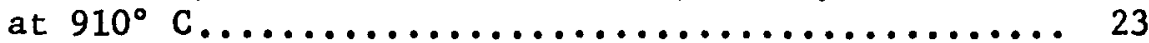

12. Thermal expansion of neodymium oxide.............. 24

13. Powder X-ray diffraction data for neodymium oxide at

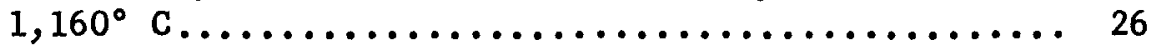

14. Thermal expansion of samarium oxide.............. 27

15. Powder X-ray diffraction data for C-type samarium oxide at $25^{\circ}$ C.......................... 28

16. Powder $X$-ray diffraction data for samarium oxide

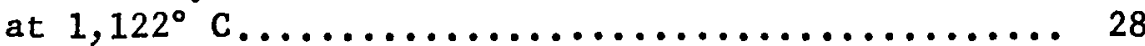

17. Thermal expansion of europium oxide.............. 29

18. Powder $\mathrm{X}$-ray diffraction data for europium oxide

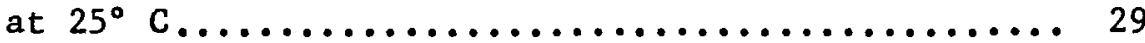

19. Thermal expansion of gadolinium oxide............ 32

20. Powder $\mathrm{X}$-ray diffraction data for gadolinium oxide at $25^{\circ}$ C............................. 32

21. Thermal expansion of dysprosium oxide............ 33

22. Thermal expansion of holmium oxide.............. 35

23. Thermal expansion of erbium oxide................ 38

24. Thermal expansion of thulium oxide................ 40

25. Thermal expansion of ytterbium oxide.............. 40

26. Powder X-ray diffraction data for ytterbium oxide

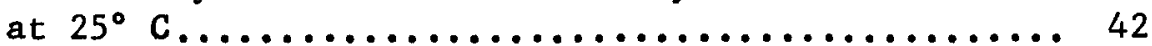

27. Thermal expansion of lutetium oxide.............. 44

28. Powder X-ray diffraction data for lutetium oxide

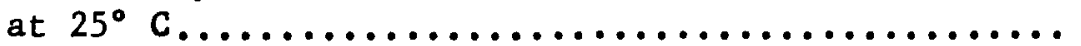




\title{
THERMAL EXPANSION AND PHASE INVERSION OF RARE-EARTH OXIDES ${ }^{\prime}$
}

by

\author{
Stephan Stecura ${ }^{2}$ and William J. Campbell ${ }^{3} 4$
}

\begin{abstract}
SUMMARY
One of the principal objectives of the Bureau of Mines program for deve1opment of superrefractory ceramic materials is to obtain fundamental data on the physical properties of refractory oxides. Elements of particular interest to research workers in the Bureau include groups III and IV of the Periodic Table and the rare-earth group. This report contains thermal expansion and phase inversion measurements on oxides of scandium, yttrium, lanthanum and 12 lanthanide series elements (promethium and terbium omitted) up to $1,350^{\circ} \mathrm{C}$. made by high-temperature X-ray diffractometer techniques.

Thermal expansion values were calculated from unit cell dimensions measured at selected temperatures; with anisotropic oxides expansion was determined parallel to each major crystallographic axis. The combined random and systematic errors in the thermal expansion values are considered to be less than 3 percent of the total expansion at $500^{\circ} \mathrm{C}$. and approximately 2 percent at $1,000^{\circ} \mathrm{C}$. No difference in expansion coefficients was observed between heating and cooling cycles for oxides that did not undergo phase inversion. Tabular data of linear expansion, in percent, linear expansion coefficients, and graphical presentation of linear expansion as a function of temperature are presented.

Phase inversions were determined by either the disappearance of the characteristic diffraction lines of the lower temperature phase, or by the appearance of the new high-temperature phase. Al1 phase inversions of the rare-earth sesquioxides were time-temperature dependent.

${ }^{1}$ Work on manuscript completed October 1960.

${ }^{2}$ Physical chemist, College Park Metallurgy Research Center, Bureau of Mines, College Park, Md.

${ }^{3}$ Supervisory physical chemist, College Park Metallurgy Research Center, Bureau of Mines, College Park, Md.

${ }^{4}$ The authors were assisted in preparing this report by Clark Grain, physical chemist, College Park Metallurgy Research Center, Bureau of Mines, College Park, Md.
\end{abstract}


Commercially available high-purity oxides were used throughout the study. Because of the common practice of the suppliers to report purity in terms of other rare earths, the suppliers' data were supplemented by optical spectrographic analyses.

\section{INTRODUCTION}

This investigation was undertaken as part of the Bureau of Mines program for the development and evaluation of high-temperature ceramic materials. One of the principal objectives of the program is to obtain fundamental data on the physical properties of refractory oxides; elements of particular interest include groups III and IV of the Periodic Table and the rare-earth group.

Many of the rare-earth oxides have high melting points, are stable at elevated temperatures in oxidizing atmospheres, and do no undergo phase inversion; therefore these oxides warrant consideration as refractory materials. Samarium and gadolinium oxides are of special interest in the nuclear field because of their very high thermal neutron absorption cross-sections.

The term "rare earths" is a misnomer because the elements are metals, not earths, and, secondly, as a group they are not particularly uncommon. Several of the lanthanide elements are more common than tin, silver, cadmium or tungsten, for example, cerium. Although most of the rare-earth oxides are still expensive (due primarily to the involved separation process) the prices have dropped rapidly during the past few years, for instance, ceric oxide is avai1able for approximately $\$ 5$ a pound in lots of 100 pounds.

Thermal expansion is one of the more important physical properties to be determined on materials considered for application at elevated temperatures. Materials with high thermal expansion coefficients must be subjected to carefully controlled heating and cooling rates to avoid mechanical failure. Phase inversions must also be predetermined because a significant volume change normally accompanies inversion.

Thermal expansion measurements by X-ray diffractometry are obtained from unit cell dimensions of each crystallographic component at selected temperatures. Phase inversions are determined by disappearance of characteristic $X$-ray lines of the low-temperature phase, by appearance of new diffraction lines, or by marked changes in the slope of the expansion-temperature relationship.

$\mathrm{X}$-ray diffractometer measurements of thermal expansion have the following advantages over dilatometer techniques :

1. Expansion in each crystallographic direction can be independently determined.

2. The expansion measurements are independent of particle size or shape or the way the crystallites fit together.

3. Samples of several grams are sufficient and binders are not required. 
4. Measurements can be made on each crystalline phase in samples containing multiple components.

Thermal expansion data are presented on smoothed curves for rapid reference and in tabular form for critical review.

\section{INSTRUMENTATION}

The thermal expansion measurements were made with a high-temperature $\mathrm{X}$-ray diffractometer furnace similar in design to the unit described by Mauer and Bolz (13). ${ }^{5}$ A general discussion of high-temperature X-ray diffractometry is given in a previous paper by Campbe11, Stecura, and Grain (3); also, descriptions of several protective devices incorporated in the furnaces are included.

The Mauer and Bolz furnace, as modified for use by the authors, is shown in figure 1. In the original Mauer and Bolz design the sample was adjusted to the focusing circle of the $\mathrm{X}$-ray diffractometer by a combined screw-lever movement. This combination resulted in a sensitive movement $(0.009$ inch per screw revolution) but had a very limited range of translation, approximately 0.025 inch. This limited range necessitated careful machining and matching of sample-support tubes and sample holders. In the modified furnace the sample is translated by a screw movement on a dove-tailed track; total translation is approximately 0.25 inch and the sensitivity is 0.046 inch per screw revolution. In addition to less critical demands on the machining of ceramic components there is no danger of tilting the sample, which might happen if the support straps of the Mauer and Bolz furnace bend unevenly. The movement is less sensitive than the original movement, but the sample height adjustment can be made to within \pm 0.002 inch by an experienced operator. This error in the height adjustment corresponds to an error of $\pm 0.02^{\circ} 2 \theta$ at $120^{\circ} 2 \theta$ and decreasing with increasing $2 \theta$.

The heating element consists of 20 gage platinum- 20 percent rhodium wire wound on an alumina winding core of 1.25 inches outside diameter, 9 threads per inch. It was found experimentally that thermal gradients across the sample, parallel to the support tube axis, were minimized if six and five turns of the heating element were used before and after the sample respectively (see fig. 2). Insulation was provided by alumina $K-28$ brick cut to fit snugly in the furnace shell.

Sample support tubes of "Vycor, "6 mullite, and alumina were used in various phases of these investigations. "Vycor" has excellent thermal shock resistant properties but is limited in use to a maximum sample temperature of approximately $1,100^{\circ} \mathrm{C}$. Although alumina can be used at higher temperatures

${ }^{5}$ Underlined numbers in parentheses refer to items in the bibliography at the end of this report. Page references refer to the pages in the items and not to those in this report.

${ }^{6}$ Reference to trade names is made to facilitate understanding and does not imply endorsement of such brands by the Bureau of Mines. 


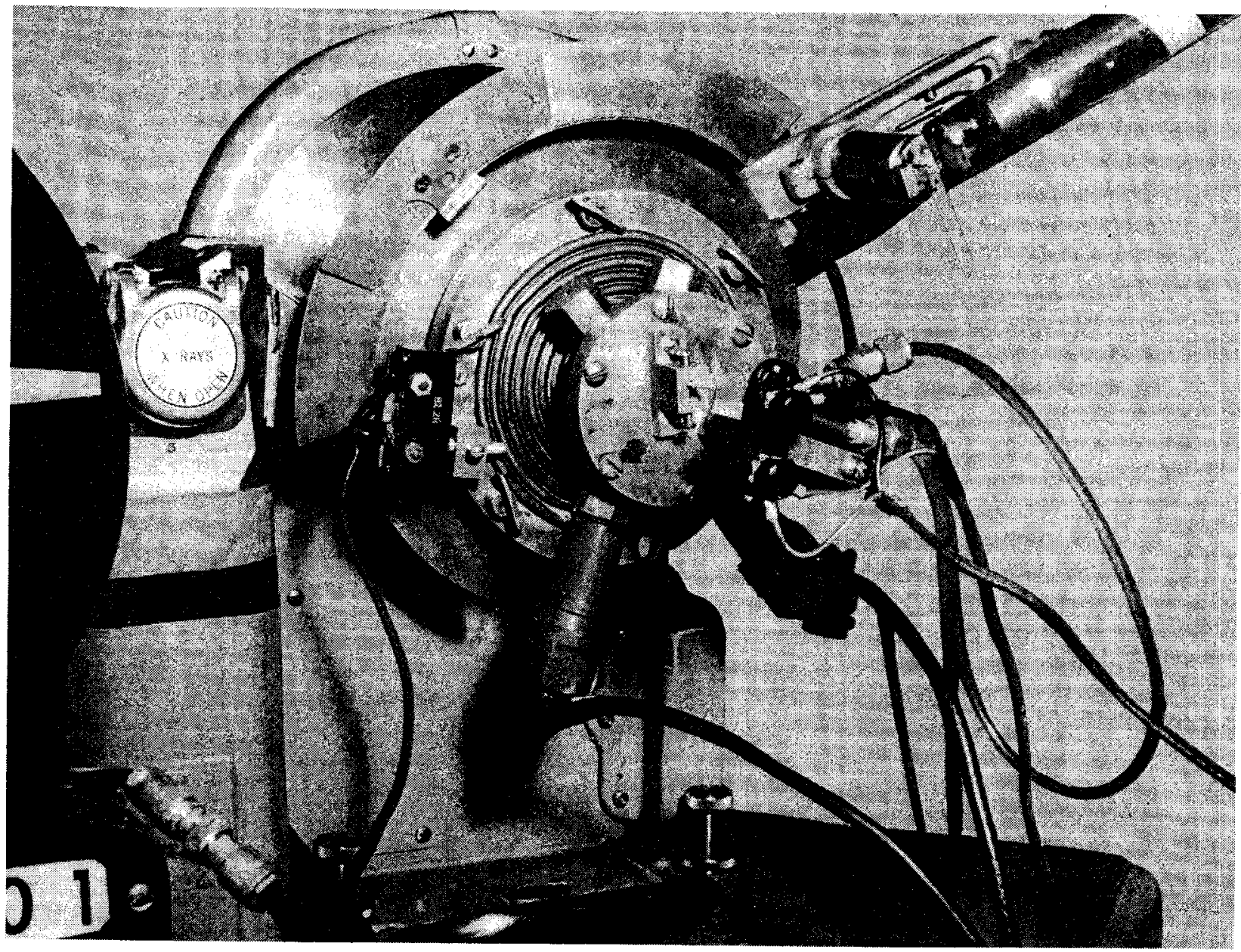

FIGURE 1. - High-Temperature X-Ray Diffractometer.

than mullite, the latter's superior thermal shock resistance makes mullite the choice because the thermal expansion measurements were limited to $1,350^{\circ} \mathrm{C}$. The mullite tubes lasted 4 to 6 weeks as long as the heating and cooling rates did not exceed $100^{\circ} \mathrm{C}$. per hour.

The mullite support tubes have the following dimensions:

Outside diameter..................498 \pm 0.001 inches

Length......................4.81 \pm 0.02 inches

Wall thickness.........................

For maximum tube life, stresses resulting from cutting and drilling for the sample holder and power leads should be relieved by annealing.

Sample holders were composed of $99.5^{+}$alumina which was mixed with a volatile binder, pressed at 2,000 pounds per square inch, then heated to $1,700^{\circ} \mathrm{C}$. The holders were machined to the proper dimensions and shape after being fired. 

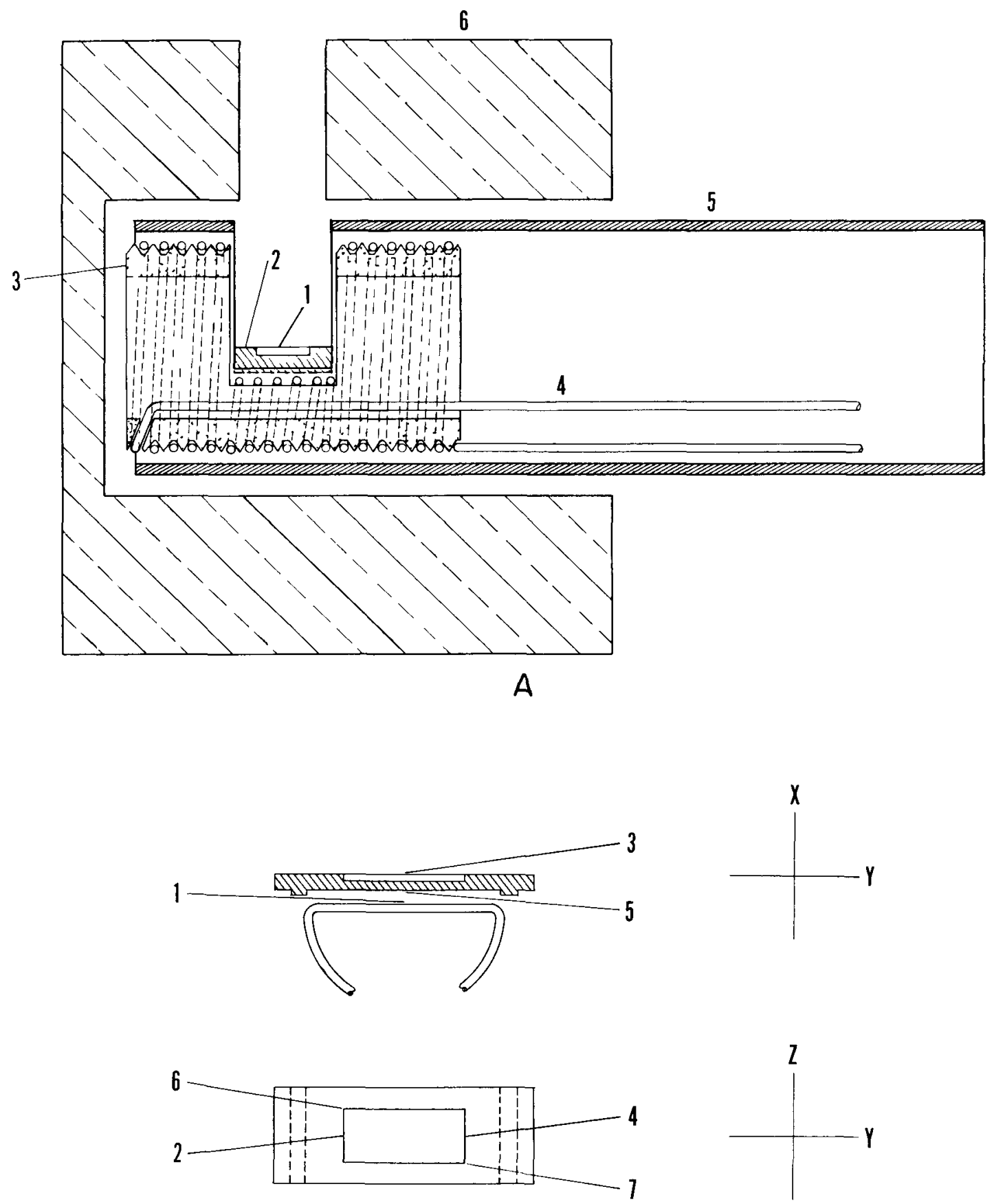

$\mathrm{B}$

FIGURE 2. - Cutaway View of Furnace Showing Heater and Thermocouple Locations. A-1, Sample; 2, sample holder; 3 , winding core; 4 , platinum-20 percent rhodium winding; 5 , sample holder support tube; 6 , insulating brick. BNumbers 1 to 7 indicate thermocouple locations. 


\section{TEMPERATURE MEASUREMENT}

Sample temperatures were determined with uncalibrated ${ }^{7} 0.005$-inch platinum and platinum-10 percent rhodium thermocouple wire embedded in the sample surface. The thermocouple junction was cut off and rewelded after each sample was studied. Thermal calibration of the X-ray diffractometer furnace (3) gives a probable error of $\pm 10^{\circ}$ to $20^{\circ} \mathrm{C}$. in the region of $1,000^{\circ} \mathrm{C}$. Additional unpublished studies indicated that the thermocouple readings were systematically low by $8^{\circ}, 5^{\circ}$, and $14^{\circ} \mathrm{C}$, using inversion temperatures of $573^{\circ}$, $811^{\circ}$, and $1,194^{\circ} \mathrm{C}$. as references for alpha quartz, barium carbonate, and calcium sulfate respectively.

The sample area in direct contact with the thermocouple is cooler than the adjoining surface area due to heat loss along the thermocouple wire; therefore, the indicated temperatures are systematically low, the error being larger for samples of low thermal conductivity. The magnitude of this error was determined by comparing the expansion of platinum powder dispersed in magnesium oxide to that of platinum as a foil. The thermocouple embedded in the surface of the metal-oxide mixture read $10^{\circ} \mathrm{C}$. lower at $1,000^{\circ} \mathrm{C}$. than that for the thermocouple welded to the platinum foil. This source of error was minimized by using fine (0.005-inch) wire and a large junction, and by running the wires through a hot zone of the furnace.

The following thermal gradient characteristics (see table 1 and fig. 2) were determined for the furnace used in these studies:

1. There is a thermal gradient of $30^{\circ}$ to $40^{\circ} \mathrm{C}$. per centimeter (at $1,000^{\circ} \mathrm{C}$. ) from the center of the sample towards each end, along the $\mathrm{Y}$ axis. The length (along $Y$ axis) of the sample in the $X$-ray beam varies with both the Bragg angle and the angular aperture of the divergence slits as expressed in the following equation.

$$
L=\frac{l \cdot y}{57.3 \times \sin \theta}
$$

$\mathrm{L}=$ length of sample in X-ray beam, centimeters,

$\ell=$ radius of goniometer, centimeters,

$\gamma=$ divergence angle, normally $1^{\circ}$ in front reflection, and $4^{\circ}$ for back reflection.

At $30^{\circ} 2 \theta$ with $1^{\circ}$ divergence slits, L equals 1.15 centimeters. Therefore, if the temperature gradient is $30^{\circ} \mathrm{C}$. per centimeter, the gradient along the portion of the sample in the X-ray beam is $\frac{1.15}{2} \times 30$, or $17^{\circ} \mathrm{C}$. at $1,000^{\circ} \mathrm{C}$.

2. The magnitude and direction of the thermal gradient across the width of the sample along the $Z$ axis, varies with the ratio of heater turns of either side of the holder and by the type and amount of insulation used to prevent heat loss down the ceramic sample support tube. On the side opposite the

\footnotetext{
${ }^{2}$ Supplier stated uncalibrated platinum and platinum- 10 percent rhodium wire
} has a reliability of \pm 0.2 percent up to $2,700^{\circ} \mathrm{F}$. 
thermocouple leads the maximum number of turns possible is five (the number of turns is controlled by the length and pitch of the core) while it is possible to have as many as 15 turns on the thermocouple side.

TABLE 1. - Determination of thermal gradients in oxidizing atmosphere furnacel

\begin{tabular}{|c|c|c|c|c|c|c|}
\hline Thermocoup $1 \mathrm{e}^{2}$ & \multicolumn{6}{|c|}{ Temperature, ${ }^{\circ} \mathrm{C}$. } \\
\hline $1 \ldots \ldots \ldots \ldots \ldots$ & 227 & 438 & 644 & 972 & 1,109 & 1,243 \\
\hline $2 \ldots \ldots \ldots \ldots \ldots$ & 178 & 351 & 525 & 808 & 932 & 1,063 \\
\hline $3 \ldots \ldots \ldots \ldots \ldots$ & 179 & 356 & 535 & 832 & 964 & 1,103 \\
\hline $4 \ldots \ldots \ldots \ldots \ldots \ldots$ & 178 & 350 & 522 & 810 & 938 & 1,074 \\
\hline $5 \ldots \ldots \ldots \ldots \ldots$ & 204 & 397 & 590 & 916 & 1,069 & 1,227 \\
\hline
\end{tabular}

In the initial studies using a winding ratio of 10 to 5 and a secondary insulator of potassium titanate inside the support tube, there was a positive thermal differential of $55^{\circ} \mathrm{C}$. (at $1,100^{\circ} \mathrm{C}$.) towards the thermocouple leads as determined by thermocouples 6 and 7 . With a winding ratio of 6 to 5 and no insulation down the support tube, the differential was reduced to $10^{\circ} \mathrm{C}$. and direction remained the same.

3. The thermal gradient through the 4-millimeter-thick alumina holder, $\mathrm{X}$ axis, was approximately $100^{\circ} \mathrm{C}$. at $1,000^{\circ} \mathrm{C}$. The depression for the powdexed oxide sample is 0.5 millimeter deep, so there is a difference of approximately $15^{\circ} \mathrm{C}$. through the total depth of sample. As the X-ray beam only penetrates about one-fifth of the sample depth, a gradient of 2 to $3^{\circ} \mathrm{C}$. is expected in the depth of sample viewed by copper Ka radiation.

A proportional control with reset and rate action permitted the use of a single thermocouple positioned on the sample for both temperature measurement and control because the rate action partly corrects for thermal lag. Temperature variations of $\pm 3^{\circ} \mathrm{C}$. at $1,000^{\circ} \mathrm{C}$. were obtained with this type of control. A cam-driven programmer was also part of this temperature control unit.

\section{SAMPIE PREPARATION}

All samples used in these studies were high-purity, commercially available oxides. The suppliers of these oxides express purity in terms of other rate earths and do not take into account non-rare-earth impurities in their stated purity, for example, $99.9+\mathrm{CeO}_{2}$ may have 0.2 percent $\mathrm{CaO}$. Because of the possible effect of impurities on thermal expansion and phase inversion characteristics of each oxide, optical spectrographic analyses were obtained on all samples investigated (see table 2). 
TABLE 2. - Optica1 spectrographic analyses of rare-earth oxides ${ }^{1}$

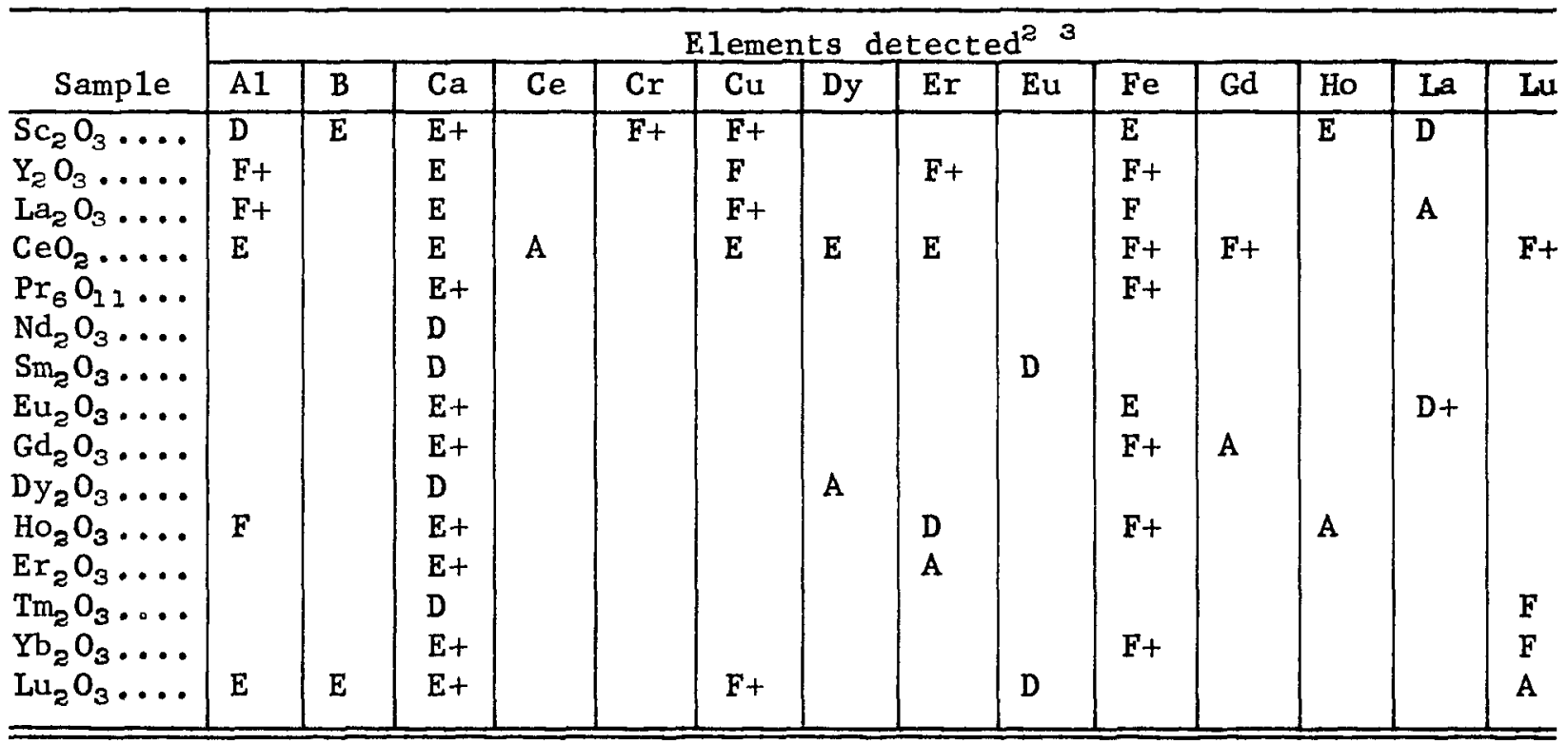

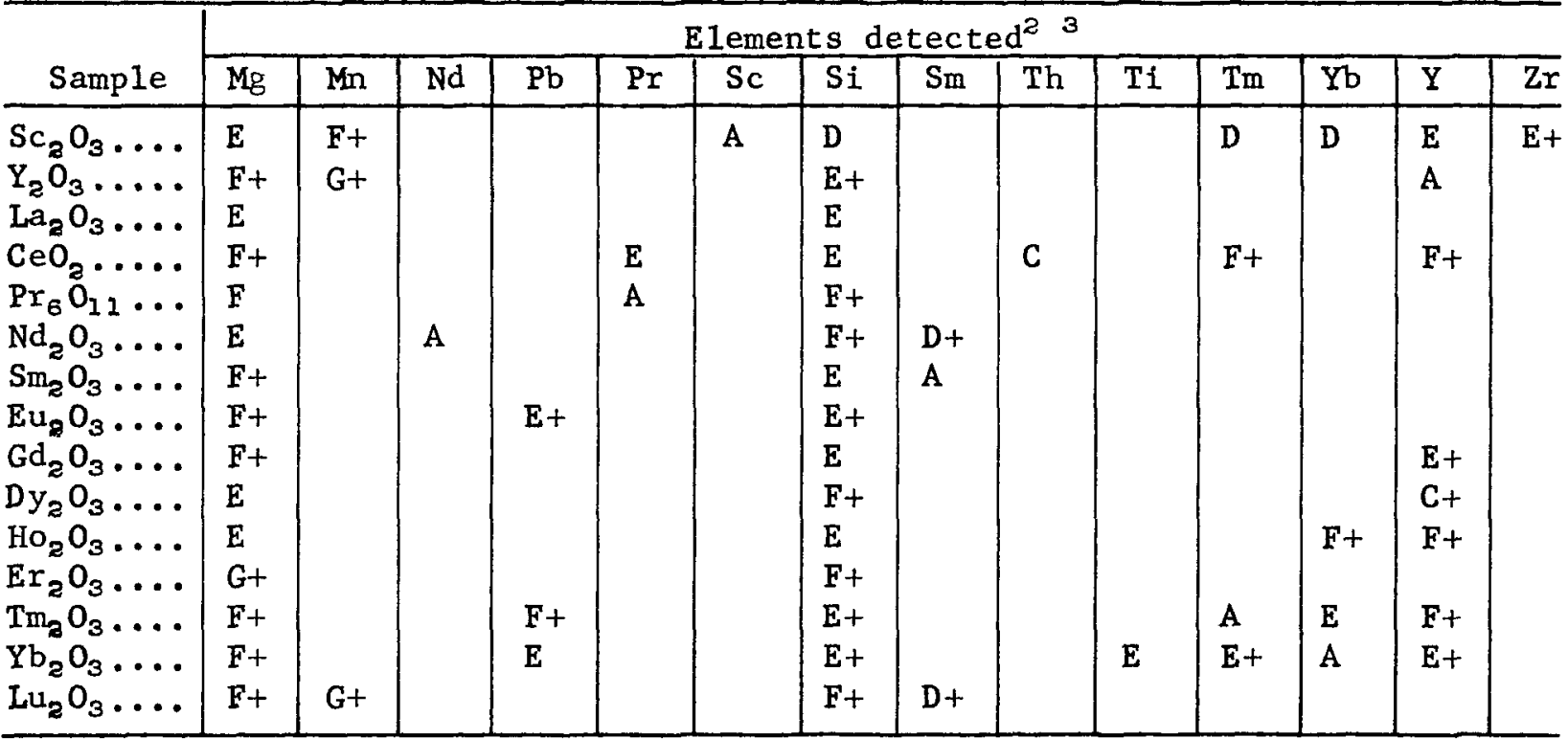

${ }^{1}$ Analyses by M. J. Peterson and J. Zink (College Park).

${ }^{2}$ Letters indicate estimates of concentration ranges in weight percent:

$\begin{array}{lllll}\text { A over } 10 & \text { D+ } & .03-.3 & \text { F+ } & .0003-.003 \\ \text { B } 1.0-10 & \text { D } & .01-.1 & \text { F } & .0001-.001 \\ \text { C+ } .3-3.0 & \text { E+ } & .003-.03 & \text { G+ } & .00003-.0003 \\ \text { C } \quad .1-1.0 & \text { E } & .001-.01 & \text { G } & .00001-.0001\end{array}$

${ }^{3}$ Elements sought but not detected: $\mathrm{Ag}$, As, $\mathrm{Ba}, \mathrm{Be}, \mathrm{Bi}, \mathrm{Cd}, \mathrm{Co}, \mathrm{Cs}, \mathrm{Ge}, \mathrm{Hg}, \mathrm{K}$, $\mathrm{Li}, \mathrm{Mo}, \mathrm{Na}, \mathrm{Nb}, \mathrm{Ni}, \mathrm{P}, \mathrm{Rb}, \mathrm{Sb}, \mathrm{Sn}, \mathrm{Sr}, \mathrm{Ta}$, $\mathrm{Tb}, \mathrm{T} 1, \mathrm{~V}, \mathrm{~W}, \mathrm{Zn}$. 
All samples were presintered in platinum crucibles to the temperature specified using a muffle type furnace with silicon carbide heaters. Calibration of the furnace shows the temperatures to be accurate to $\pm 30^{\circ} \mathrm{C}$. in the $1,000^{\circ}$ to $1,300^{\circ} \mathrm{C}$. range. After preliminary sintering the oxides were packed into alumina sample holders and refired. The sample surfaces were leveled after firing by polishing them with a high density alumina disc.

\section{CALCULATIONS}

Linear expansion (percent) and linear expansion coefficients are determined from precision measurements of the Bragg reflection angle. Utilizing Bragg's equation the interplanar spacing can be calculated from the diffraction angle:

$$
\mathrm{n} \lambda=2 \mathrm{~d} \sin \theta
$$

where

$$
\begin{aligned}
& \mathrm{n}=\text { order of reflection } \\
& \lambda=\text { wavelength of X-radiation, A } \\
& \mathrm{d}=\text { interplanar spacing, A } \\
& \theta=\text { Bragg angle }
\end{aligned}
$$

The unit cell parameters are determined from the following equations relating $d$ and $a$ or $c$ for cubic and hexagonal systems.

Cubic

$$
a=d \sqrt{h^{2}+k^{2}+1^{2}}
$$

where

$$
\begin{aligned}
\mathrm{a} & =\text { unit cell parameter } \\
\mathrm{h}, \mathrm{k}, \mathrm{l} & =\text { Miller indices }
\end{aligned}
$$

Hexagona 1

$$
\begin{aligned}
& \frac{1}{d^{2}}=\frac{4}{3}\left(\frac{h^{2}+h k+k^{2}}{a^{2}}\right)+\frac{1^{2}}{c^{2}} \\
& a=d \sqrt{\frac{4}{3}\left(h^{2}+h k+k^{2}\right)+\frac{1^{2}}{c^{2} / a^{2}}} \\
& c=d \sqrt{\frac{4 a^{2}}{3 c^{2}}\left(h^{2}+h k+k^{2}\right)+1^{2}}
\end{aligned}
$$

For the cubic system, measurement of a single back reflection line is sufficient (after furnace alignment) whereas a minimum of two lines must be measured for the hexagonal systems in order to solve for a and $c$ by simultaneous equations. Whenever it is possible to choose reflecting planes such as hk0 or $00 \ell$ for the hexagonal systems then a and $c$ respectively can be independently determined.

Thermal expansion was calculated by extrapolating the lattice parameter-temperature curve to $0^{\circ} \mathrm{C}$. to get a value of $a_{0}$. Using this value the linear expansion and the linear expansion coefficient are calculated from the following equations. 


$$
\text { linear expansion (percent) }=\frac{a_{t}-a_{0}}{a_{0}} \times 100
$$

where

$$
\begin{aligned}
& a_{0}=\text { lattice parameter at } 0^{\circ} \mathrm{C} . \\
& a_{t}=\text { lattice parameter at } t^{\circ} \mathrm{C} . \\
& \text { Linear expansion coefficient }=\frac{a_{t}-a_{0}}{a_{0}} \times \frac{1}{t^{\circ} \mathrm{C}} .
\end{aligned}
$$

\section{ACCURACY OF EXPANSION MEASUREMENTS}

To obtain accurate expansion measurements, the sample surface was adjusted to the focusing circle at each temperature to correct for shrinkage or expansion. At room temperature sample alignment is similar to ordinary diffractometry, but the height adjustment adds one additional parameter. A modified Soller slit arrangement was satisfactory for the initial alignment (3). At elevated temperatures a height adjustment technique originally suggested by Mauer and Bolz (13) was used. Mauer and Bolz observed that unit cel1 measurements are very sensitive to sample displacement in the front reflection (low $2 \theta$ ) region with rapidly decreasing sensitivity in the back reflection $\left(>90^{\circ} 2 \theta\right)$ region. The error in the parameter measurement due to sample displacement is minimized by adjusting the sample height until two diffraction lines, one in the front and one in the back reflection regions respectively, give the same unit cell parameter.

Previous studies by Mauer and Bolz (13) show that the height adjustment error has the same order of magnitude as the error in measuring the diffraction angle. Assuming the error in measuring the diffraction angle to be $\pm 0.01^{\circ} 2 \theta$, the resultant error in the thermal expansion measurement can be calculated.

Isotropic expansion $\frac{\Delta d}{d}$ is equal to $\frac{\Delta a}{a}$ since

$$
d=\frac{a}{\sqrt{h^{2}+k^{2}+1^{2}}}
$$

or $a=k d$ for a given reflection. At low temperatures $\Delta d$ is small; therefore, small experimental errors in measuring $2 \theta$ results in large percentage errors in the thermal expansion measurements. At higher temperature $\Delta \mathrm{d}$ becomes large enough so that small experimental errors in $2 \theta$ measurements have little effect on the value of $\frac{\Delta d}{d}$; however, at this point temperature measurements become more difficult. Table 3 lists calculated errors for alpha alumina using the 410 reflection and considering

$$
\frac{\Delta \mathrm{d}}{\mathrm{d}}=\frac{\Delta \mathrm{a}}{\mathrm{a}}
$$

experimental data obtained for alpha alumina are in agreement with the calculated deviations. The errors in the $\frac{\Delta \mathrm{d}}{\mathrm{d}}$ measurement are of a random nature, whereas the temperature errors are both random and systematic. The systematic errors are probably the most important. As mentioned earlier the thermocouple readings in the temperature range near $800^{\circ} \mathrm{C}$. read $5^{\circ} \mathrm{C}$. low; therefore the temperature error is -2 to $-8^{\circ} \mathrm{C}$. A critical evaluation of errors in the 
expansion measurements is given by Mauer and Bolz (13); their conclusions are in general agreement with those of the authors.

TABLE 3. - Calculated errors for linear expansion measurements using diffractometer techniques ${ }^{1}$

\begin{tabular}{|c|c|c|c|c|c|}
\hline \multirow[b]{2}{*}{$\begin{array}{c}\text { Temperature } \\
0 \mathrm{C} .\end{array}$} & \multirow[b]{2}{*}{$\begin{array}{l}\text { Degrees, } \\
2 \theta\end{array}$} & \multirow[b]{2}{*}{$\underset{\mathrm{A}}{\mathrm{d}} \underset{\mathrm{spacing}}{ }$} & \multirow{2}{*}{$\begin{array}{c}\Delta d, \\
\text { degrees } \\
2 \theta\end{array}$} & \multicolumn{2}{|c|}{ Calculated error, percent } \\
\hline & & & & $\begin{array}{c}\text { Sample } \\
\text { alinement }\end{array}$ & $\begin{array}{l}\text { Temperature } \\
\text { measurement }\end{array}$ \\
\hline $\begin{array}{r}28 \ldots \ldots \ldots \ldots \ldots \\
278 \ldots \ldots \ldots \ldots \ldots \\
527 \ldots \ldots \ldots \ldots \ldots \\
807 \ldots \ldots \ldots \ldots \ldots \\
1,066 \ldots \ldots \ldots \ldots \ldots\end{array}$ & $\begin{array}{l}117.78 \\
117.45 \\
117.08 \\
116.61 \\
116.08\end{array}$ & $\begin{array}{r}0.89964 \\
.90120 \\
.90298 \\
.90526 \\
.90786\end{array}$ & $\begin{array}{r}0.00156 \\
.00334 \\
.00562 \\
.00822\end{array}$ & $\begin{array}{l}6.0 \\
2.8 \\
1.7 \\
1.1\end{array}$ & $\begin{array}{l}1.5 \\
1.0 \\
1.0 \\
2.0\end{array}$ \\
\hline
\end{tabular}

${ }^{1}$ For 410 reflection of alpha alumina assuming isotropic expansion.

${ }^{3}$ Error in linear expansion measurements due to alignment is equal to

$\frac{9.4 \times 10^{-3}}{\Delta d}$ based on a \pm error of $0.01^{\circ} 2 \theta ; \pm 0.01^{\circ} 2 \theta= \pm 4.7 \times 10^{-5} \mathrm{~A}$ at $117^{\circ} 2 \theta$.

${ }^{3}$ Temperature error is a combination of systematic and random errors.

A study was made by the authors to determine the agreement of thermal expansion measurements obtained from each of two furnaces of very similar design operated by different personnel. The average deviation among duplicate runs by each worker was less than \pm 1 percent, with a maximum deviation of \pm 2 percent at $1,200^{\circ} \mathrm{C}$. Comparison of the results from each furnace and measurements made by each worker indicates no systematic differences. No significant differences were observed between data taken on heating and cooling cycles or on successive runs (see fig. 3).

The authors' interest in lattice parameter measurements was in precision, not absolute accuracy. Thermal expansion is determined from the change in parameter with temperature; therefore, absolute values are not required. The parameters were determined from a single reflection; extrapolation methods to $180^{\circ} 2 \theta$ were not used in any of these studies. For this reason some of the parameter values may disagree with published parameter values at room temperature in the second or third decimal place.

\section{EXPERIMENT RESULTS AND DISCUSSION}

$$
\text { Scandium Oxide }\left(\mathrm{Sc}_{8} \mathrm{O}_{3}\right)
$$

Sample: Scandium sesquioxide, supplied by Heavy Minerals Co., Chattanooga, Tenn., was stated to be 99.5 percent $\mathrm{Sc}_{2} \mathrm{O}_{3}$ in regard to rare-earth content. Optical spectrographic analyses (see table 2) indicated major nonrare-earth impurities were aluminum and silicon.

Sample Preparation: The sample was sintered at $1,150^{\circ} \mathrm{C}$. for 24 hours, packed into an alumina sample holder, sintered at $1,200^{\circ} \mathrm{C}$, cooled to $300^{\circ} \mathrm{C}$. and placed in a vacuum desiccator for storage. 


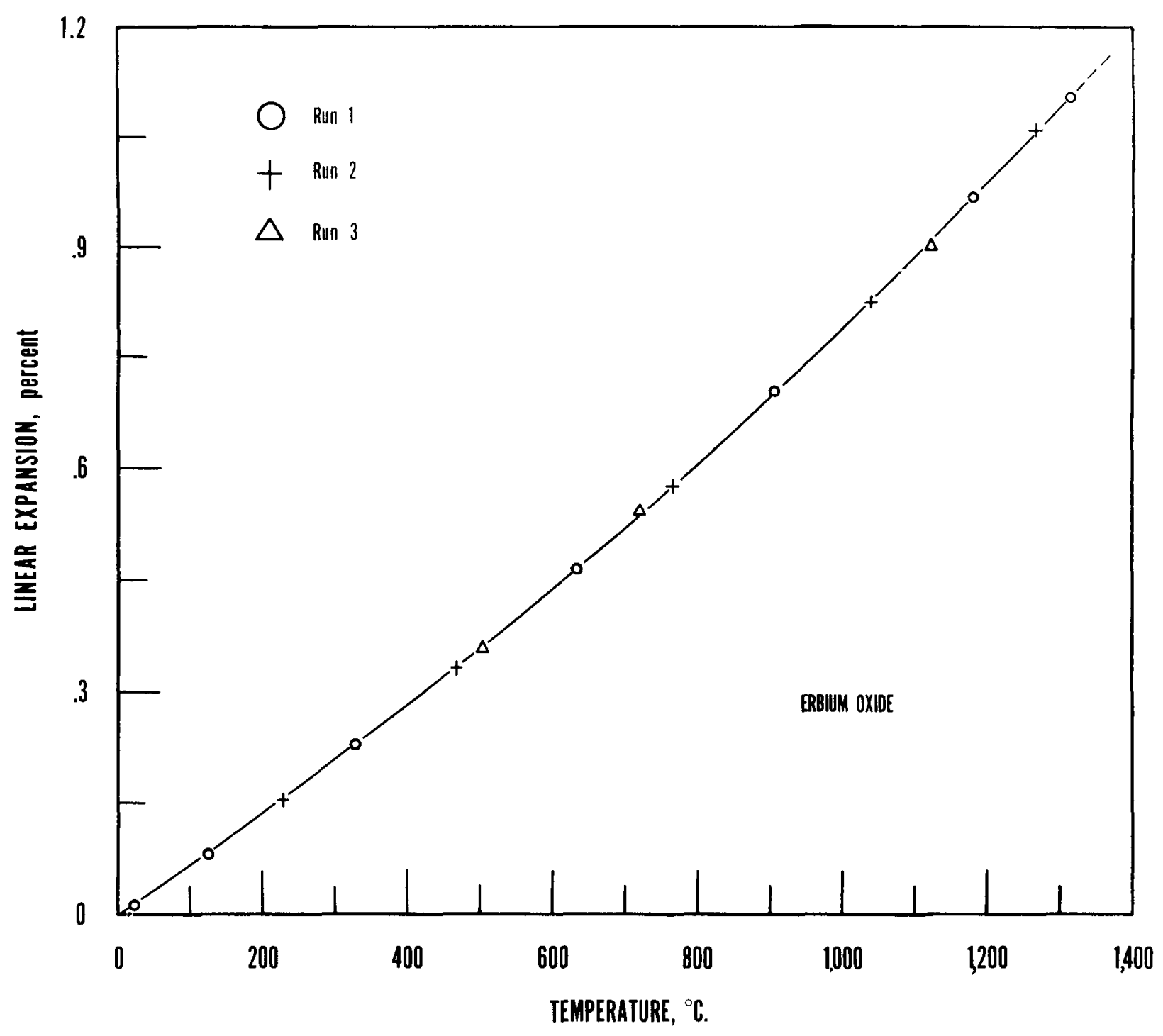

FIGURE 3. - Precision of Thermal Expansion Measurements.

Method: The 222 and 10.4.0 lines were used for furnace alinement. Therma1 expansion was determined from the 10.3.1 and 10.4.0 lines; maximum deviation between values from both lines was less than \pm 2 percent above $500^{\circ} \mathrm{C}$.

Results: See table 4 and figure 4.

Discussion: Scandium sesquioxide is cubic with thallium oxide type structure (rare-earth oxide type $\mathrm{C}$ ) and $16 \mathrm{Sc}_{2} \mathrm{O}_{3}$ per unit cell, lattice parameter at $25^{\circ} \mathrm{C}$. is $9.845 \mathrm{~A}(19$, vol. $3,1954, \mathrm{p} .27)$. No phase inversion was observed in this study $\left(25^{\circ}-1,320^{\circ} \mathrm{C}.\right)$. 


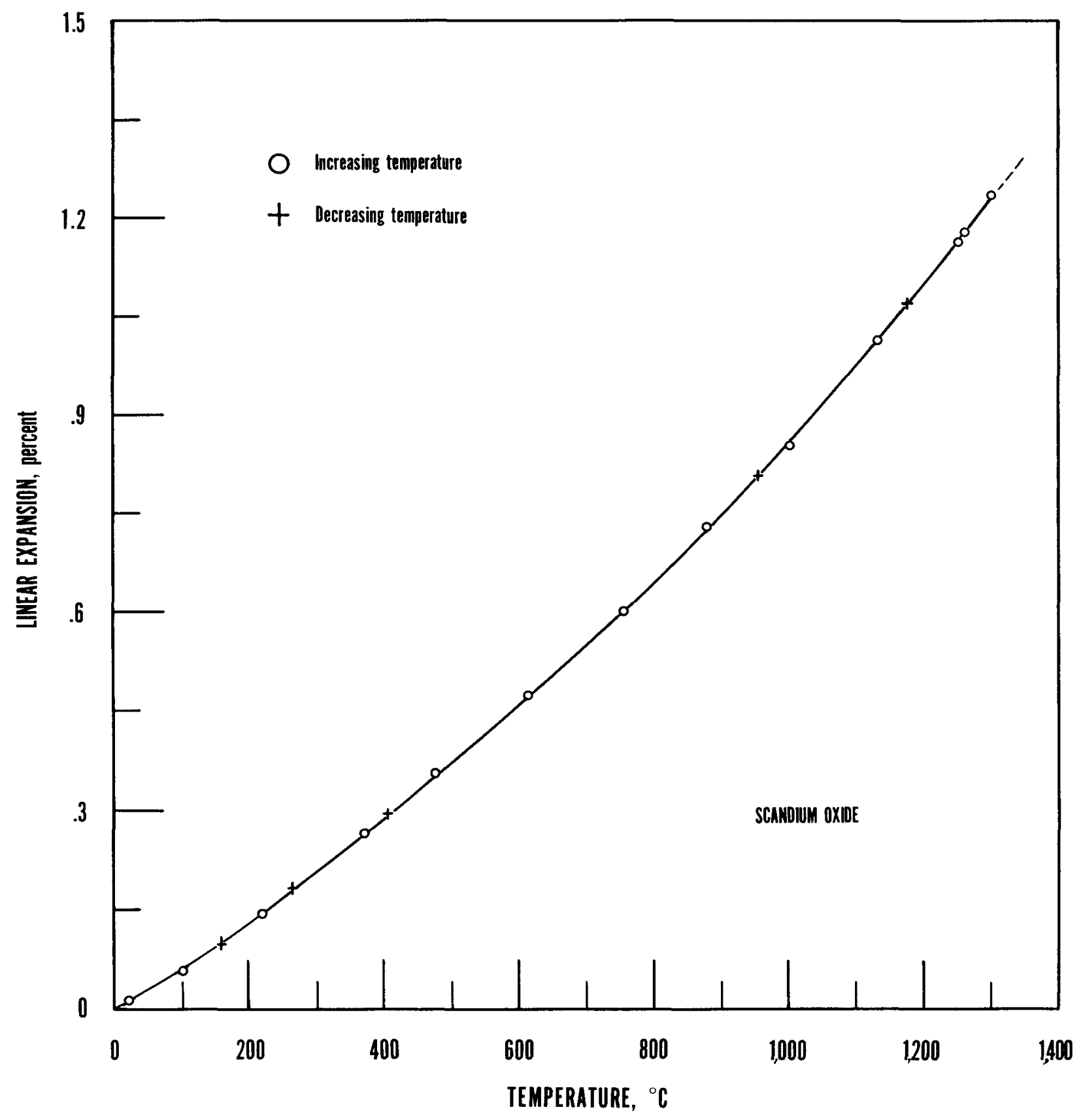

FIGURE 4. - Thermal Expansion of Scandium Sesquioxide. 
TABIE 4. - Thermal expansion of scandium oxide

\begin{tabular}{|c|c|c|c|}
\hline $\begin{array}{c}\text { Temperature, } \\
\circ \mathrm{C} .\end{array}$ & $\begin{array}{l}\text { Unit cel1 } \\
\text { parameter, A }\end{array}$ & $\begin{array}{c}\text { Linear expansion, } \\
\text { percent }\end{array}$ & $\begin{array}{l}\text { Linear expansion } \\
\text { coefficient }\left(\times 10^{6}\right)\end{array}$ \\
\hline $\begin{array}{r}0 \ldots \ldots \ldots \\
23 \ldots \ldots \ldots \\
103 \ldots \ldots \ldots \\
220 \ldots \ldots \\
375 \ldots \ldots \ldots \\
476 \ldots \ldots \ldots \\
613 \ldots \ldots \\
755 \ldots \ldots \\
877 \ldots \ldots \\
999 \ldots \ldots \\
1,130 \ldots \ldots \\
1,250 \ldots \ldots \\
1,260 \ldots \ldots \\
1,300 \ldots \ldots \\
1,175 \ldots \ldots \ldots \\
953 \ldots \ldots \ldots \\
405 \ldots \ldots \ldots \\
266 \ldots \ldots \\
157 \ldots \ldots \ldots \\
\ldots \ldots\end{array}$ & $\begin{array}{l}9.8428 \\
9.8440 \\
9.8483 \\
9.8571 \\
9.8690 \\
9.8777 \\
9.8894 \\
9.9017 \\
9.9147 \\
9.9267 \\
9.9426 \\
9.9573 \\
9.9606 \\
9.9644 \\
9.9483 \\
9.9224 \\
9.8718 \\
9.8607 \\
9.8524\end{array}$ & $\begin{array}{l}0.00 \\
.012 \\
.056 \\
.145 \\
.266 \\
.355 \\
.473 \\
.598 \\
.731 \\
.852 \\
1.014 \\
1.163 \\
1.179 \\
1.235 \\
1.072 \\
.809 \\
.295 \\
.182 \\
.098\end{array}$ & $\begin{array}{l}5.2 \\
5.4 \\
6.6 \\
7.1 \\
7.4 \\
7.7 \\
7.9 \\
8.3 \\
8.5 \\
8.9 \\
9.3 \\
9.3 \\
9.5 \\
9.1 \\
8.4 \\
7.2 \\
6.8 \\
6.2\end{array}$ \\
\hline
\end{tabular}

Yttrium Oxide $\left(\mathrm{Y}_{2} \mathrm{O}_{3}\right)$

Sample: Yttrium sesquioxide, supplied by Heavy Minerals Co., Chattanooga, Tenn., was stated to be 99.9 percent $\mathrm{Y}_{2} \mathrm{O}_{3}$ in regard to rare-earth content. Optical spectrographic analyses (see table 2) indicated major non-rare-earth impurities were calcium and silicon.

Sample Preparation: The sample was sintered at $1,250^{\circ} \mathrm{C}$. for 24 hours, packed into an alumina sample holder, sintered at $1,350^{\circ} \mathrm{C}$. for 12 hours, cooled to $150^{\circ} \mathrm{C}$. and placed in a vacuum desiccator for storage.

Method: The 222 and 12.4.2 lines were used for furnace alinement. Thermal expansion was determined from the 12.4.2 line.

Results: See table 5 and figure 5 .

Discussion: Yttrium sesquioxide is cubic with thallium oxide type structure (rare-earth oxide type $C$ ) and $16 \mathrm{Y}_{2} \mathrm{O}_{3}$ per unit ce11; 1attice constant at $27^{\circ} \mathrm{C}$. is $10.604 \mathrm{~A}(19$, vol. $3,1954, \mathrm{pP} .28-29)$. No phase inversion was observed in this study $\left(25^{\circ}-1,300^{\circ} \mathrm{C}.\right)$. These results agree with those reported by Curtis (4) and Staritzky (17). Curtis (6) reported an overal1 linear expansion coefficient for $0^{\circ}$ to $1,400^{\circ} \mathrm{C}$. of

$$
9.3 \times 10^{-6} \mathrm{in./in} \text {. per }{ }^{\circ} \mathrm{C} \text {.; }
$$

however this value does not agree with his graph. This graphical data indicates $8.2 \times 10^{-6}$ for $0^{\circ}$ to $1,400^{\circ} \mathrm{C}$. and 8.9 from $500^{\circ}$ to $1,400^{\circ} \mathrm{C}$; these values are in agreement with those obtained by the authors. 
TABLE 5. - Thermal expansion of yttrium oxide

\begin{tabular}{|c|c|c|c|}
\hline $\begin{array}{c}\text { Temperature, } \\
\circ \mathrm{C} .\end{array}$ & $\begin{array}{c}\text { Unit cell } \\
\text { parameter, A }\end{array}$ & $\begin{array}{c}\text { Linear expansion, } \\
\text { percent }\end{array}$ & $\begin{array}{l}\text { Linear expansion } \\
\text { coefficient }\left(x \quad 10^{6}\right)\end{array}$ \\
\hline 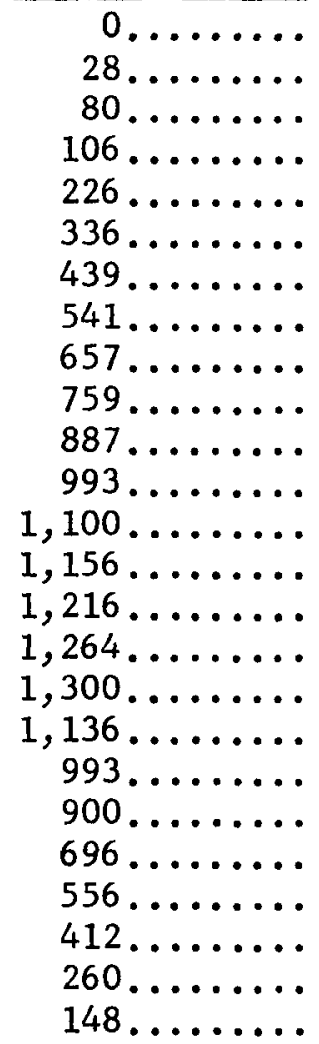 & $\begin{array}{l}10.6012 \\
10.6032 \\
10.6071 \\
10.6079 \\
10.6186 \\
10.6274 \\
10.6365 \\
10.6461 \\
10.6571 \\
10.6671 \\
10.6798 \\
10.6910 \\
10.7019 \\
10.7085 \\
10.7150 \\
10.7210 \\
10.7250 \\
10.7065 \\
10.6910 \\
10.6815 \\
10.6606 \\
10.6475 \\
10.6347 \\
10.6213 \\
10.6122\end{array}$ & $\begin{array}{r}0.00 \\
.019 \\
.056 \\
.073 \\
.164 \\
.247 \\
.333 \\
.424 \\
.527 \\
.622 \\
.741 \\
.847 \\
.950 \\
1.012 \\
1.074 \\
1.130 \\
1.168 \\
.993 \\
.847 \\
.758 \\
.560 \\
.437 \\
.316 \\
.190 \\
.104\end{array}$ & $\begin{array}{l}6.7 \\
7.0 \\
6.8 \\
7.2 \\
7.3 \\
7.5 \\
7.8 \\
8.0 \\
8.1 \\
8.3 \\
8.5 \\
8.6 \\
8.7 \\
8.8 \\
8.9 \\
8.9 \\
8.7 \\
8.5 \\
8.4 \\
8.0 \\
7.8 \\
7.6 \\
7.2 \\
7.0\end{array}$ \\
\hline
\end{tabular}

Lanthanum Oxide $\left(\mathrm{La}_{2} \mathrm{O}_{3}\right)$

Sample: Lanthanum sesquioxide, supplied by Lindsay Chemical Co., West Chicago, I11. (their code 528), was stated to be 99.9 percent $\mathrm{La}_{2} \mathrm{O}_{3}$ in regard to total rare-earth content. Optical spectrographic analyses (see table 2) indicated that the major non-rare-earth impurities were calcium, magnesium and silicon.

Sample Preparation: Because lanthanum oxide is very hygroscopic, special precautions were necessary. The sample was sintered at $1,000^{\circ} \mathrm{C}$. for 24 hours, cooled rapidly to $500^{\circ} \mathrm{C}$. and placed in a vacuum desiccator until room temperature was reached. The sample was packed into an alumina sample holder, sintered at $1,000^{\circ} \mathrm{C}$. for 24 hours, cooled to $750^{\circ} \mathrm{C}$. and placed in a vacuum desiccator for storage. Thermal expansion measurements were started immediately upon positioning the sample in the diffractometer furnace. Preliminary 


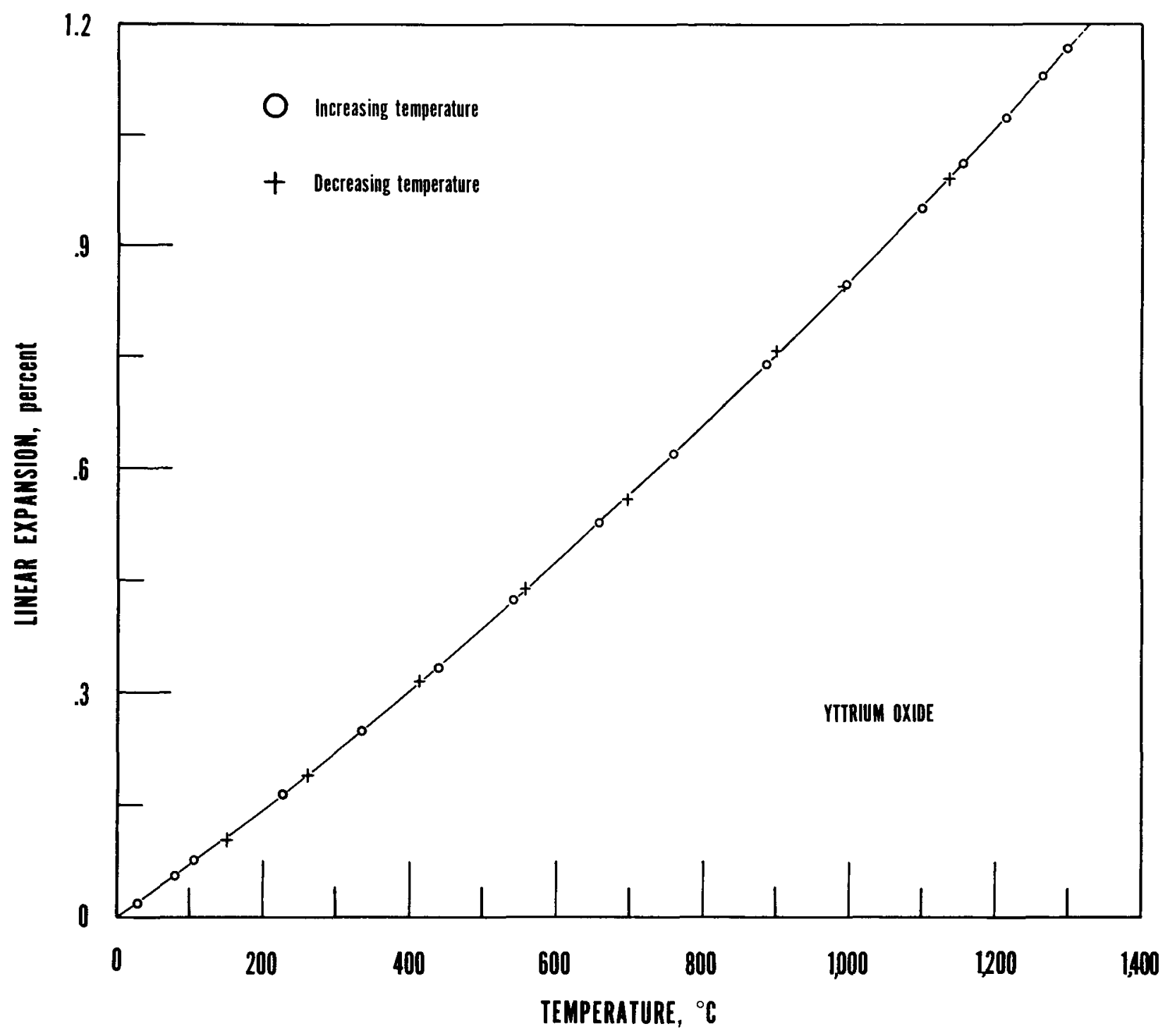

FIGURE 5. - Thermal Expansion of Yttrium Sesquioxide.

studies indicated that no significant amount of moisture was absorbed by the calcined sample in the brief period of time, less than one hour, needed to bring the sample above $150^{\circ} \mathrm{C}$.

Results: See table 6 and figure 6 .

Discussion: Lanthanum sesquioxide is hexagonal (rare-earth oxide type A) with one $\mathrm{La}_{8} \mathrm{O}_{3}$ per unit cell; lattice parameters at $26^{\circ} \mathrm{C}$. are 3.9373 and 6.1299A for a and c respectively (19, vol. 3, 1954, pp. 33-34). Quil1 (16) reported $\mathrm{La}_{2} \mathrm{O}_{3}$ to exist in both the $\mathrm{A}$ and $\mathrm{C}$ forms up to $500^{\circ} \mathrm{C}$. , above that temperature only the $A$ form was stable. The authors found the sample, as received, to be a mixture of $A$ type $\mathrm{La}_{3} \mathrm{O}_{3}$ plus $\mathrm{La}(\mathrm{OH})_{3}$. Samples fired to 
$1,200^{\circ}$ to $1,300^{\circ} \mathrm{C}$, and cooled to room temperature exhibited the A type only. High temperature $X$-ray diffraction studies showed an unreported high temperature phase which is not stable at room temperature (see table 7). If the calcined $A$ type $\mathrm{La}_{2} \mathrm{O}_{3}$ is heated from room temperature (at a rate of $15^{\circ} \mathrm{C}$. per minute) the new phase appears near $1,100^{\circ} \mathrm{C}$. When the sample was cooled rapidly to $930^{\circ} \mathrm{C}$. and then to $660^{\circ} \mathrm{C}$. the same high temperature phase was present. Expansion data for the a-axis (see fig. 6) shows a marked change in expansion near $965^{\circ} \mathrm{C}$. , which may be the inversion point for the A type oxide. Since the phase inversions are time-temperature dependent, further studies will be required to obtain accurate inversion points. 8

TABLE 6. - Thermal expansion of lanthanum oxide

\begin{tabular}{|c|c|c|c|c|c|c|}
\hline \multirow{2}{*}{$\begin{array}{c}\text { Temperature, } \\
\circ \mathrm{C} . \\
\end{array}$} & \multicolumn{2}{|c|}{$\begin{array}{l}\text { Unit cel1 } \\
\text { parameter, A }\end{array}$} & \multicolumn{2}{|c|}{$\begin{array}{c}\text { Linear expansion, } \\
\text { percent }\end{array}$} & \multicolumn{2}{|c|}{$\begin{array}{l}\text { Linear expansion } \\
\text { coefficient }\left(\times 10^{6}\right)\end{array}$} \\
\hline & $a$ & $c$ & $a$ & $c$ & $a$ & $c$ \\
\hline $0 \ldots \ldots \ldots \ldots$ & 3.9365 & 6.1277 & 0.00 & 0.00 & & \\
\hline $23 \ldots$ & 3.9372 & 6.1295 & .018 & .029 & 7.8 & 12.6 \\
\hline $162 \ldots \ldots$ & 3.9418 & 6.1420 & .135 & .233 & 8.3 & 14.3 \\
\hline $288 \ldots \ldots \ldots$ & 3.9467 & 6.1546 & .259 & .439 & 8.9 & 15.2 \\
\hline $423 \ldots$ & 3.9520 & 6.1674 & .394 & .648 & 9.3 & 15.3 \\
\hline $527 \ldots$ & 3.9560 & 6.1784 & .495 & .827 & 9.3 & 15.6 \\
\hline $646 \ldots$ & 3.9614 & 6.1912 & .633 & 1.036 & 9.7 & 16.0 \\
\hline $779 \ldots$ & 3.9677 & 6.2067 & .793 & 1.289 & 10.1 & 16.5 \\
\hline $924 \ldots$ & 3.9748 & 6.2251 & .973 & 1.590 & 10.5 & 17.2 \\
\hline $941 \ldots$ & 3.9754 & 6.2268 & .988 & 1.617 & 10.4 & 17.1 \\
\hline $852 \ldots$ & 3.9717 & 6.2156 & .884 & 1.435 & 10.3 & 16.8 \\
\hline $758 \ldots$ & 3.9666 & 6.2040 & .765 & 1.245 & 10.0 & 16.4 \\
\hline $558 \ldots$ & 3.9573 & 6.1812 & .528 & .873 & 9.4 & 15.6 \\
\hline $338 \ldots$ & 3.9487 & 6.1595 & .310 & .519 & 9.1 & 15.3 \\
\hline $214 \ldots \ldots \ldots \ldots$ & 3.9437 & 6.1474 & .183 & .322 & 8.5 & 15.0 \\
\hline
\end{tabular}

TABLE 7. - Powder X-ray diffraction data for lanthanum oxide at $1,100^{\circ} \mathrm{C}$.

\begin{tabular}{c|c||c|c}
\hline d-spacing, A & $\frac{I}{I_{100}} \times 100$ & d-spacing, $A$ & $\frac{I}{I_{100} \times 100}$ \\
\hline 3.416 & 34 & 2.456 & 17 \\
3.314 & 24 & 2.349 & 31 \\
3.215 & 14 & 1.978 & 42 \\
3.093 & 31 & 1.774 & 28 \\
2.992 & 100 & 1.670 & 31 \\
2.603 & 14 & 1.654 & 21 \\
\hline
\end{tabular}

${ }^{8}$ After completion of this manuscript the authors became aware of a recent paper discussing phase inversion of rare-earth oxides; our work supplements the data reported in this paper. Roth, R. S., and Schneider, S. J., Phase Equilibria in Systems Involving the Rare-Earth Oxides. Part I. Polymorphism of the Oxides of the Trivalent Rare-Earth Ions: Jour. Research Nat. Bureau of Standards, vol. 64A, 1960, pp. 309-316. 


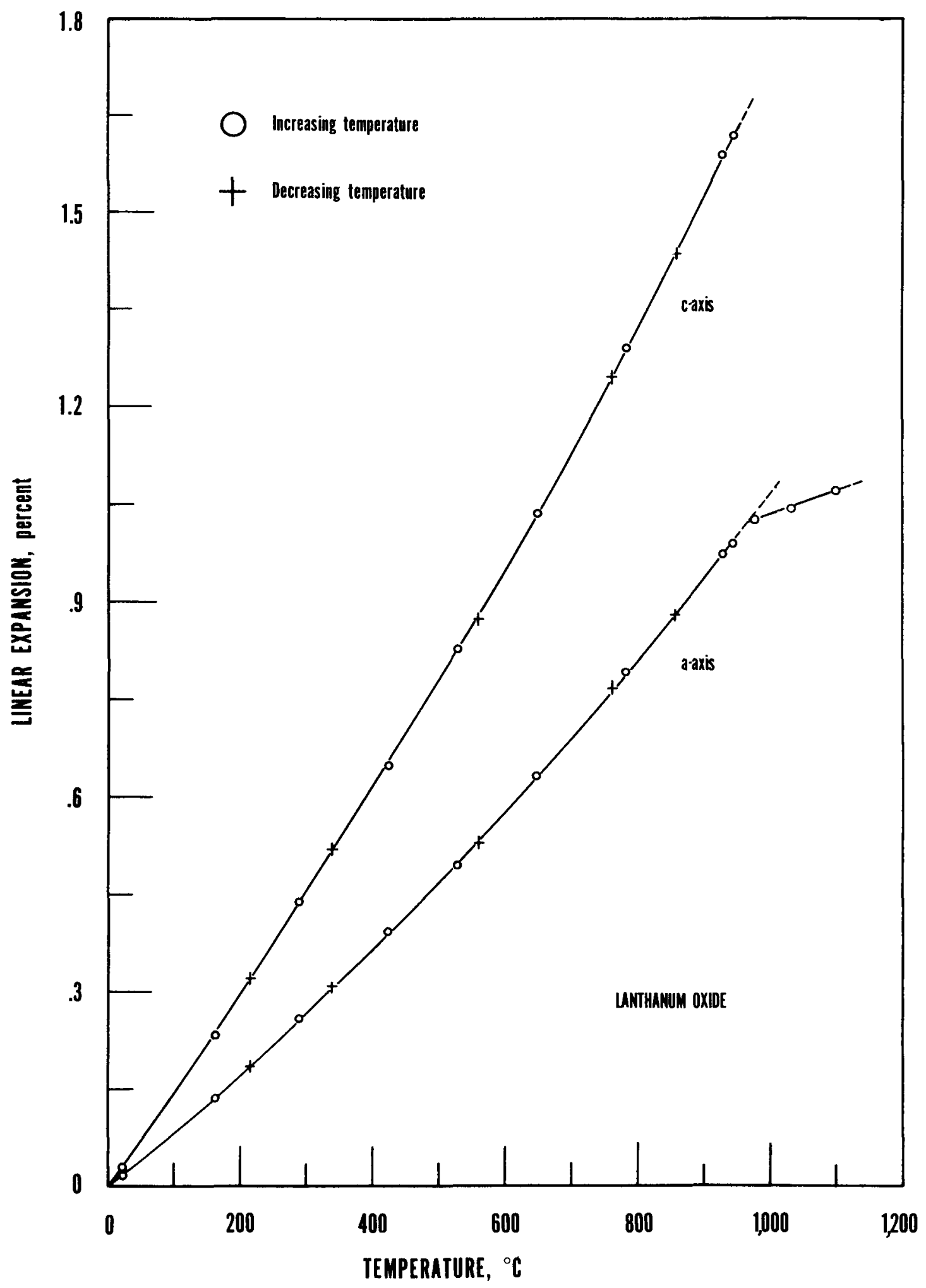

FIGURE 6. - Thermal Expansion of Lanthanum Sesquioxide. 
Cerium Dioxide $\left(\mathrm{CeO}_{2}\right)$

Sample: Cerium dioxide, supplied by Lindsay Chemical Co., West Chicago, I11. (their code 215), was stated to be 99.9 percent $\mathrm{CeO}_{3}$ in regard to total rare-earth content. Optical spectrographic analyses (see table 2) indicated that the major non-rare-earth impurity was thorium.

Sample Preparation: The sample was sintered at $1,350^{\circ} \mathrm{C}$. for 24 hours, packed into an alumina sample holder, sintered at $1,450^{\circ} \mathrm{C}$. for 12 hours, cooled to $300^{\circ} \mathrm{C}$. and placed in a vacuum desiccator for storage.

Method: The 111 and 621 lines were used for furnace alinement. Therma1 expansion was determined from the 531 and 620 lines; maximum deviation between values from both lines was less than \pm 2 percent above $500^{\circ} \mathrm{C}$.

Results: See table 8 and figure 7.

Discussion: Cerium dioxide is cubic with fluorite type structure and 4 $\mathrm{CeO}_{2}$ per unit cell; lattice parameter at $26^{\circ} \mathrm{C}$. is $5.4110 \mathrm{~A}$ (19, vo1. 1, 1953, pp. 56-57). The crystal structure of nonstoichiometric $\mathrm{CeO}_{\mathrm{x}}$ (where $\mathrm{x}$ is less than 2) is discussed by Honig (11). No phase inversion inversion was observed in this study $\left(25^{\circ}-1,310^{\circ} \mathrm{C}\right.$.). Thermal expansion was obtained at increasing temperatures only because the furnace winding broke after the measurements at $1,310^{\circ} \mathrm{C}$. were completed. Preliminary studies had shown that no hysteresis occurred in the expansion-temperature relationship.

\section{TABLE 8. - Thermal expansion of cerium dioxide}

\begin{tabular}{|c|c|c|c|}
\hline $\begin{array}{c}\text { Temperature, } \\
\circ \mathrm{C} .\end{array}$ & $\begin{array}{l}\text { Unit cel1 } \\
\text { parameter, A }\end{array}$ & $\begin{array}{c}\text { Linear expansion, } \\
\text { percent }\end{array}$ & $\begin{array}{l}\text { Linear expansion } \\
\text { coefficient }\left(x 10^{8}\right)\end{array}$ \\
\hline $\begin{array}{r}0 \ldots \ldots \ldots \\
26 \ldots \ldots \ldots \\
118 \ldots \ldots \ldots \\
140 \ldots \ldots \\
220 \ldots \ldots \\
268 \ldots \ldots \ldots \\
346 \ldots \ldots \\
415 \ldots \ldots \\
503 \ldots \ldots \\
570 \ldots \ldots \\
616 \ldots \ldots \\
720 \ldots \ldots \\
845 \ldots \ldots \\
975 \ldots \ldots \\
1,131 \ldots \ldots \\
1,200 \ldots \ldots \\
1,261 \ldots \ldots \\
1,310 \ldots \ldots\end{array}$ & $\begin{array}{l}5,4085 \\
5.4100 \\
5.4153 \\
5.4165 \\
5.4215 \\
5.4245 \\
5.4295 \\
5.4335 \\
5.4395 \\
5.4436 \\
5.4471 \\
5.4542 \\
5.4635 \\
5.4736 \\
5.4862 \\
5.4919 \\
5.4963 \\
5.5003\end{array}$ & $\begin{array}{l}0.00 \\
.028 \\
.126 \\
.148 \\
.240 \\
.296 \\
.388 \\
.462 \\
.573 \\
.649 \\
.712 \\
.845 \\
1.017 \\
1.204 \\
1.437 \\
1.541 \\
1.623 \\
1.697\end{array}$ & $\begin{array}{l}10.7 \\
10.6 \\
10.5 \\
10.9 \\
11.0 \\
11.2 \\
11.1 \\
11.3 \\
11.3 \\
11.5 \\
11.7 \\
12.0 \\
12.3 \\
12.7 \\
12.8 \\
12.8 \\
12.9\end{array}$ \\
\hline
\end{tabular}




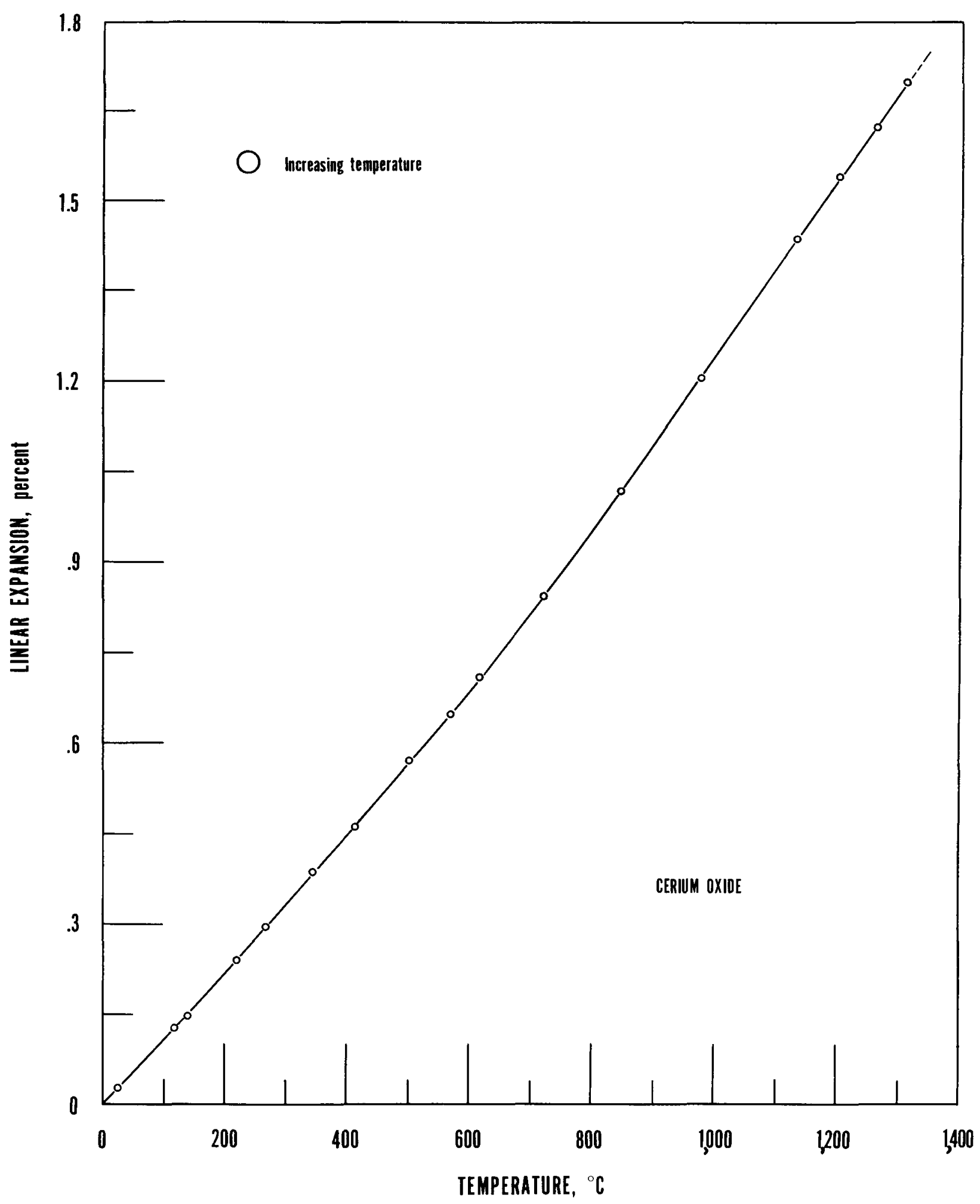

FIGURE 7. - Thermal Expansion of Cerium Dioxide. 
Praseodymium Oxide $\left(\operatorname{Pr}_{B} O_{1}\right)$

Sample: Praseodymium oxide, supplied by Lindsay Chemical Co., West Chicago, I11. (their code 729.9), was stated to be 99.9 percent $\operatorname{Pr}_{8} \mathrm{O}_{12}$ in regard to total rare-earth content. Optical spectrographic analyses (see table 2) indicated that the major non-rare-earth impurity was calcium.

Sample Preparation: The sample was sintered at $950^{\circ} \mathrm{C}$. for 24 hours, packed into an alumina sample holder, sintered at $1,050^{\circ} \mathrm{C}$. for 12 hours, cooled to $300^{\circ} \mathrm{C}$. and placed in a vacuum desiccator for storage. Because praseodymium oxide is hygroscopic, precautions against prolonged exposure to moist air must be taken.

Method: The 222 and 622 lines were used for furnace alinement. Thermal expansion was determined from the 1022 line.

Results: See table 9 and figure 8.

Discussion: Praseodymium oxide $\left(\mathrm{PrO}_{1} .83\right)$ was reported in the ASTM X-ray diffraction card 6-0329 to be cubic with a lattice parameter of $5.4695 \mathrm{~A}$ at $25^{\circ} \mathrm{C}$. Curtis (5) stated that $\mathrm{Pr}_{2} \mathrm{O}_{3}$ is a rare-earth oxide type $\mathrm{C}$ with a unit ce11 of $10.913 \pm 0.006 \mathrm{~A}$; the powder pattern is very similar to the ASTM data for $\operatorname{PrO}_{1.83}$. The sample received from Lindsay, 1 isted as $\operatorname{Pr}_{6} \mathrm{O}_{21}\left(\mathrm{PrO}_{1.83}\right)$, also agrees with the ASTM card. Honig (11) summarized, in his review on the $\mathrm{PrO}_{\mathrm{x}}$ system, that under equilibrium conditions near $300^{\circ} \mathrm{C} ., \mathrm{x}=1.98$; for $350^{\circ}$ to $450^{\circ} \mathrm{C} ., \mathrm{x}=1.83$; equilibrium conditions were obtained in several hours. In the region of $725^{\circ}$ to $1,000^{\circ} \mathrm{C} ., \mathrm{x}=1.72$; equilibrium is achieved in several minutes. In the intermediate temperature ranges the sample composition is quite variable. Samples heated to elevated temperatures in air and cooled slowly will always have a composition close to $x=1.83$.

TABIE 9. - Thermal expansion of praseodymium oxide

\begin{tabular}{|c|c|c|c|}
\hline $\begin{array}{c}\text { Temperature, } \\
\circ \mathrm{C} . \\
\end{array}$ & $\begin{array}{c}\text { Unit cel1 } \\
\text { parameter, A }\end{array}$ & $\begin{array}{c}\text { Linear expansion, } \\
\text { percent }\end{array}$ & $\begin{array}{l}\text { Linear expansion } \\
\text { coefficient }\left(\times 10^{6}\right)\end{array}$ \\
\hline $\begin{array}{r}0 \ldots \ldots \ldots \\
25 \ldots \ldots \ldots \\
101 \ldots \ldots \ldots \\
206 \ldots \ldots \ldots \\
208 \ldots \ldots \ldots \\
426 \ldots \ldots \ldots \\
520 \ldots \ldots \\
625 \ldots \ldots \ldots \\
726 \ldots \ldots \ldots \\
778 \ldots \ldots \ldots \\
830 \ldots \ldots \\
886 \ldots \ldots \ldots \\
950 \ldots \ldots \\
989 \ldots \ldots \ldots \\
1,020 \ldots \ldots \ldots \\
\ldots\end{array}$ & $\begin{array}{l}10.9055 \\
10.9084 \\
10.9180 \\
10.9304 \\
10.9412 \\
10.9631 \\
10.9797 \\
11.0079 \\
11.0371 \\
11.0556 \\
11.0705 \\
11.0891 \\
11.1080 \\
11.1133 \\
11.1190\end{array}$ & $\begin{array}{l}0.00 \\
.027 \\
.115 \\
.228 \\
.327 \\
.528 \\
.680 \\
.939 \\
1.207 \\
1.376 \\
1.513 \\
1.683 \\
1.824 \\
1.906 \\
1.958\end{array}$ & $\begin{array}{l}10.8 \\
11.3 \\
11.0 \\
11.6 \\
12.3 \\
13.0 \\
15.0 \\
16.6 \\
17.6 \\
18.2 \\
18.9 \\
19.2 \\
19.2 \\
19.1\end{array}$ \\
\hline
\end{tabular}




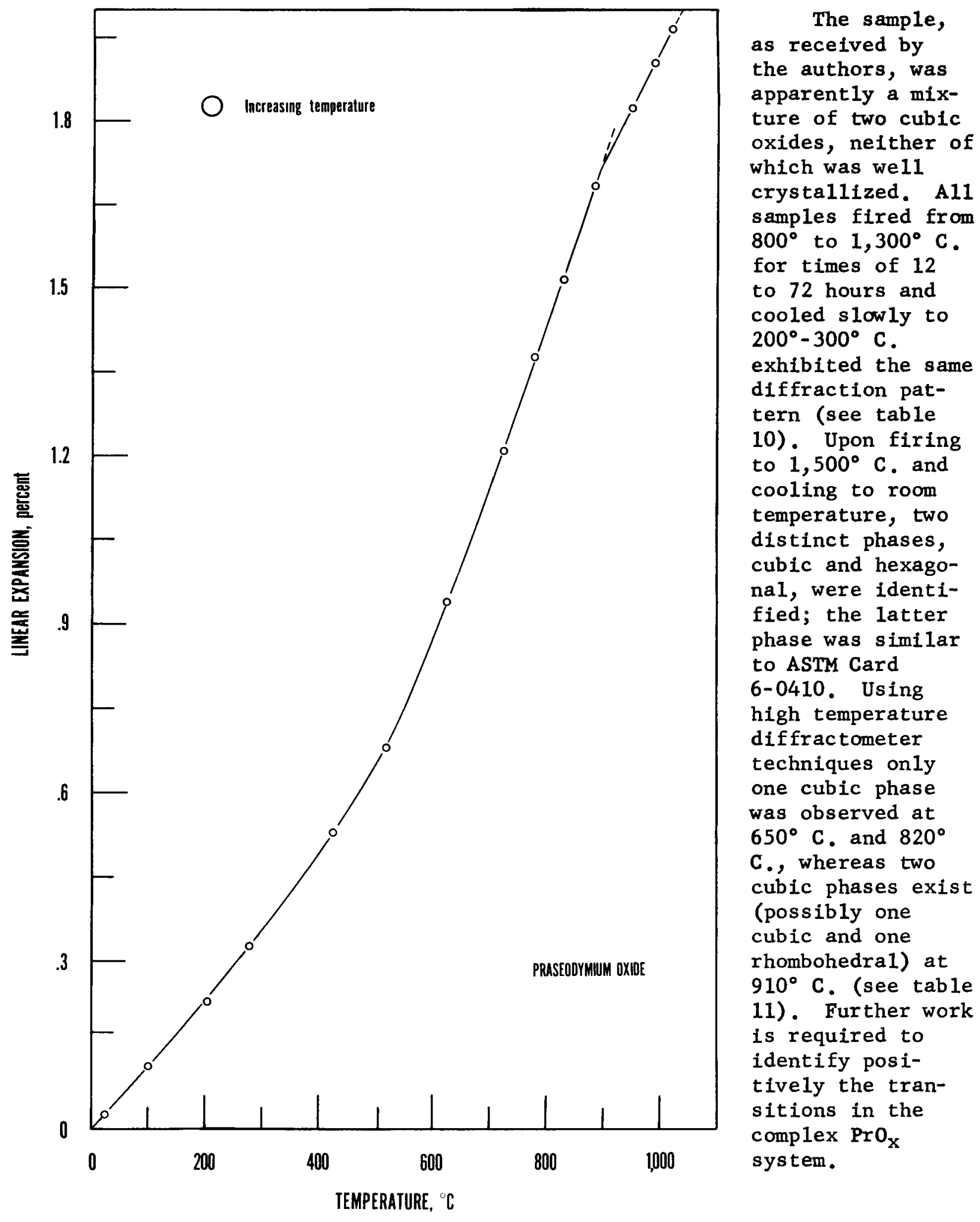

FIGURE 8. - Thermal Expansion of Praseodymium Oxide $\left(\mathrm{Pr}_{6} \mathrm{O}_{11}\right)$. 
TABLE 10. - Powder X-ray diffraction data for praseodymium oxide at $25^{\circ} \mathrm{C} .1$

\begin{tabular}{l|c|c|c||c|c|c|c}
\hline hkI & d-spacing, A & $\frac{I}{I_{100}} \times 100$ & a, A & hkI & d-spacing, A & $\frac{I}{I_{100}} \times 100$ & a, A \\
\hline 111 & 3.147 & 100 & 5.45 & 422 & 1.115 & 1 & 5.464 \\
200 & 2.726 & 38 & 5.452 & 511 & 1.0516 & 5 & 5.465 \\
220 & 1.929 & 40 & 5.456 & 440 & .9634 & 1 & 5.467 \\
311 & 1.646 & 31 & 5.458 & 531 & .9244 & 2 & 5.468 \\
222 & 1.576 & 1 & 5.460 & 600 & .9113 & 1 & 5.468 \\
400 & 1.365 & 1 & 5.460 & 620 & .8641 & 1 & 5.466 \\
331 & 1.253 & 1 & 5.462 & 533 & .8334 & 1 & 5.467 \\
420 & 1.222 & 1 & 5.463 & & & & \\
\hline
\end{tabular}

${ }^{1}$ Fired at $1,000^{\circ} \mathrm{C}$. for 12 hours.

TABLE 11. - Powder X-ray diffraction data for praseodymium oxide at $910^{\circ} \mathrm{C}$.

\begin{tabular}{l|c||c|c}
\hline & $\frac{I}{I_{100}} \times 100$ & $\mathrm{~d}$-spacing, $\mathrm{A}$ & $\frac{\mathrm{I}}{\mathrm{I}_{100}} \times 100$ \\
\hline 3.218 & 38 & 1.268 & 6 \\
3.184 & 100 & 1.0853 & 3 \\
2.758 & 48 & 1.0654 & 5 \\
2.093 & 8 & 1.0493 & 4 \\
1.963 & 30 & 1.0039 & 3 \\
1.952 & 30 & .9850 & 3 \\
1.679 & 13 & .9403 & 4 \\
1.671 & 28 & .9232 & 4 \\
1.665 & 26 & .9135 & 3 \\
1.596 & 10 & .8799 & 2 \\
1.382 & 7 & .8766 & 3 \\
\hline
\end{tabular}

Neodymium Oxide $\left(\mathrm{Nd}_{\mathbf{3}} \mathrm{O}_{3}\right)$

Sample: Neodymium sesquioxide, supplied by Lindsay Chemical Co., West Chicago, Ill. (their code 629.9), was stated to be 99.9 percent $\mathrm{Nd}_{2} \mathrm{O}_{3}$ in regard to total rare-earth content. Optical spectrographic analyses (see table 2) indicated that the major non-rare-earth impurities were calcium and magnesium.

Sample Preparation: The sample was sintered at $1,100^{\circ} \mathrm{C}$. for 24 hours, packed into an alumina sample holder, sintered at $1,100^{\circ} \mathrm{C}$ for 12 hours, cooled to $750^{\circ} \mathrm{C}$. and placed in a vacuum desiccator for storage. 
Method: The 100, 300, and 215 lines were used for furnace alinement, the latter for final critical adjustment. Thermal expansion was determined from the 213, 311, and 215 lines using simultaneous equations for the a and c parameters.

Results: See table 12 and figure 9.

Discussion: Neodymium sesquioxide is polymorphic, existing in both the $A$ and $C$ forms. The thermal expansion measurements in this investigation was restricted to the hexagonal phase (rare-earth oxide type A) having a lanthanum oxide-type structure and 1 molecule of $\mathrm{Nd}_{3} \mathrm{O}_{3}$ per unit cel1, lattice parameters at $26^{\circ} \mathrm{C}$. of 3.831 and $5.999 \mathrm{~A}$ for a and $\mathrm{c}$ axis respectively (19, vo1. 4, 1955, p. 26).

TABLE 12. - Thermal expansion of neodymium oxide

\begin{tabular}{|c|c|c|c|c|c|c|}
\hline \multirow{2}{*}{$\begin{array}{c}\text { Temperature, } \\
{ }_{0} \text { C. }\end{array}$} & \multicolumn{2}{|c|}{$\begin{array}{l}\text { Unit cell } \\
\text { parameter, A }\end{array}$} & \multicolumn{2}{|c|}{$\begin{array}{l}\text { Linear expansion, } \\
\text { percent }\end{array}$} & \multicolumn{2}{|c|}{$\begin{array}{l}\text { Linear expansion } \\
\text { coefficient }\left(\times 10^{6}\right)\end{array}$} \\
\hline & $a$ & c & $a$ & c & $a$ & c \\
\hline 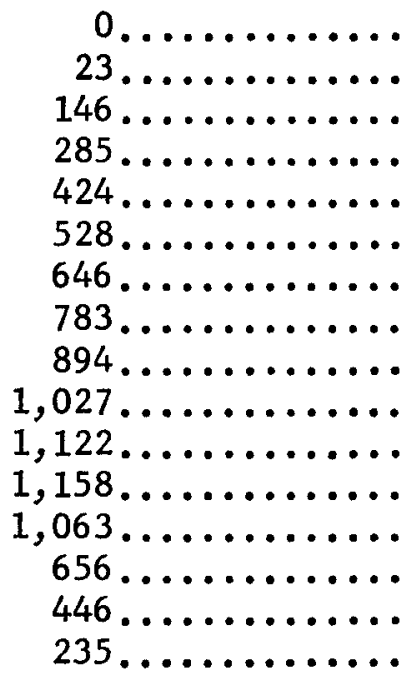 & $\begin{array}{l}3.8287 \\
3.8293 \\
3.8332 \\
3.8386 \\
3.8438 \\
3.8479 \\
3.8525 \\
3.8579 \\
3.8621 \\
3.8679 \\
3.8720 \\
3.8738 \\
3.8696 \\
3.8525 \\
3.8444 \\
3.8369\end{array}$ & $\begin{array}{l}5.9950 \\
5.9970 \\
6.0082 \\
6.0222 \\
6.0352 \\
6.0454 \\
6.0574 \\
6.0715 \\
6.0839 \\
6.1005 \\
6.1116 \\
6.1165 \\
6.1043 \\
6.0580 \\
6.0373 \\
6.0171\end{array}$ & $\begin{array}{r}0.00 \\
.016 \\
.118 \\
.259 \\
.394 \\
.502 \\
.622 \\
.761 \\
.872 \\
1.024 \\
1.131 \\
1.178 \\
1.068 \\
.622 \\
.409 \\
.214\end{array}$ & $\begin{array}{l}0.00 \\
.034 \\
.220 \\
.454 \\
.671 \\
.841 \\
1.041 \\
1.276 \\
1.483 \\
1.760 \\
1.945 \\
2.027 \\
1.823 \\
1.051 \\
.706 \\
.369\end{array}$ & $\begin{array}{r}6.9 \\
8.0 \\
9.0 \\
9.2 \\
9.5 \\
9.6 \\
9.7 \\
9.7 \\
9.9 \\
10.0 \\
10.1 \\
10.0 \\
9.4 \\
9.1 \\
9.1\end{array}$ & $\begin{array}{l}14.7 \\
15.0 \\
15.9 \\
15.8 \\
15.9 \\
16.1 \\
16.2 \\
16.5 \\
17.1 \\
17.3 \\
17.5 \\
17.1 \\
16.0 \\
15.8 \\
15.7\end{array}$ \\
\hline
\end{tabular}

Quil1 (16) in a review article states that $\mathrm{Nd}_{2} \mathrm{O}_{3}$ exists in the $\mathrm{C}$ form below $775^{\circ} \mathrm{C}$. and the A type at higher temperatures. Brauer and Gradinger obtained $A$ type $\mathrm{Nd}_{2} \mathrm{O}_{3}$ from ignition of oxalates and hydroxides to $750^{\circ} \mathrm{C}$. while the $\mathrm{C}$ form was obtained from nitrates. Blum and Maguire (1) reported conversion of cubic to hexagonal $\mathrm{Nd}_{2} \mathrm{O}_{3}$ beginning at approximately $600^{\circ} \mathrm{C}$.; at $800^{\circ} \mathrm{C}$. only a trace of the cubic phase remained. Lohberg (12) found the cubic form by heating the oxide to $700^{\circ} \mathrm{C}$. for 3 hours. It could be converted to the hexagonal form by heating it to $1,000^{\circ} \mathrm{C}$. and then converted back to cubic form by heating it at $700^{\circ} \mathrm{C}$. 


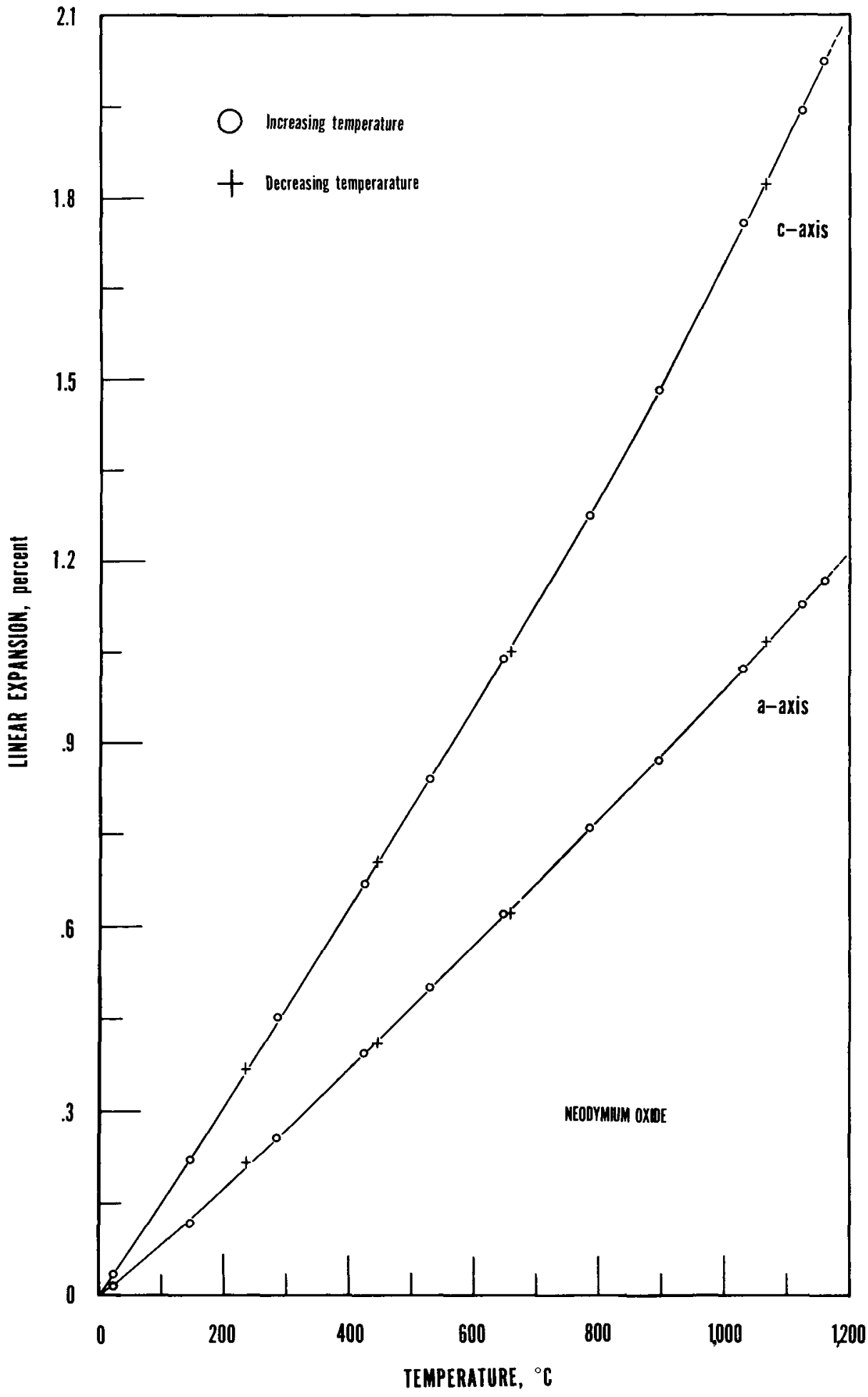

FIGURE 9. - Thermal Expansion of Neodymium Sesquioxide.
The authors' starting sample was principally A-type oxide plus some hydroxide. Samples fired at $1,050^{\circ}$ to $1,500^{\circ}$ $C$. and cooled to room temperature were A type only. One sample of $A$ type only was maintained at $700^{\circ} \mathrm{C}$. for 20 hours then cooled quickly to room temperature. Only the A form was present; this finding, however, is not in agreement with the results reported by Lohberg (12). By high temperature diffractometer techniques two phases were found at $1,160^{\circ} \mathrm{C} .$, the $A$ phase and an unknown major phase. After this temperature was maintained for 10 hours, only the new phase was present (see table 13). This unstable high temperature phase began to appear to approximately $1,070^{\circ} \mathrm{C}$. When the diffractometer furnace was cooled rapidly to $930^{\circ} \mathrm{C}$. and then $610^{\circ} \mathrm{C}$. , the unstable high temperature phase was still present. 
TABLE 13. - Powder X-ray diffraction data for neodymium oxide at $1,160^{\circ} \mathrm{C}$.

\begin{tabular}{c|c||c|c}
\hline d-spacing, $A$ & $\frac{I}{I_{100}} \times 100$ & $d-$-spacing, $A$ & $\frac{I}{I_{100} \times 100}$ \\
\hline 4.015 & 13 & 2.410 & 20 \\
3.666 & 17 & 2.259 & 40 \\
3.536 & 21 & 2.112 & 45 \\
3.429 & 47 & 1.948 & 29 \\
3.356 & 37 & 1.936 & 48 \\
3.278 & 77 & 1.910 & 17 \\
3.177 & 57 & 1.762 & 28 \\
3.112 & 41 & 1.742 & 57 \\
3.074 & 43 & 1.636 & 44 \\
3.060 & 32 & 1.621 & 37 \\
2.941 & 100 & 1.617 & 37 \\
2.738 & 40 & 1.470 & 15 \\
2.710 & 20 & 1.389 & 29 \\
2.587 & 41 & 1.241 & 13 \\
& & 1.200 & 13 \\
\hline
\end{tabular}

Samarium Oxide $\left(\mathrm{Sm}_{3} \mathrm{O}_{3}\right)$

Sample: Samarium sesquioxide, supplied by Lindsay Chemical Co., West Chicago, I11. (their code 823), was stated to be 99.9 percent $\mathrm{Sm}_{2} \mathrm{O}_{3}$ in regard to rare-earth content. Optical spectrographic data (see table 2) indicated that the major non-rare-earth impurities were calcium and silicon.

Sample Preparation: The sample was sintered at $850^{\circ} \mathrm{C}$. for 24 hours, packed in an alumina sample holder, sintered at $900^{\circ} \mathrm{C}$. for 24 hours, cooled to $300^{\circ} \mathrm{C}$. and placed in a vacuum desiccator for storage.

Method: The 222 and 622 1ines were used for furnace alinement. Thermal expansion was determined from the 622 lines.

Results: See table 14 and figure 10 .

Discussion: Samarium sesquioxide is polymorphic; the cubic phase (rareearth oxide type $C$ ) was used for the expansion measurements reported in this investigation (see table 15). Templeton and Dauben (20) reported a cubic $\mathrm{Sm}_{2} \mathrm{O}_{3}$, a of $10.932 \pm 0.009 \mathrm{~A}$, with no mention of thermal history of the sample. The sample, as received was cubic; after 24 hours at $850^{\circ} \mathrm{C}$., it was still cubic. However, after treatment at $950^{\circ} \mathrm{C}$. for 12 hours, two phases, cubic and monoclinic (rare-earth oxide type B), were present. Samples fired at various temperatures on the range $1,000^{\circ} \mathrm{C}$. to $1,500^{\circ} \mathrm{C}$. for periods of from 3 to 72 hours and then cooled to room temperature were B type only. In the high temperature diffractometer the C phase was formed at $920^{\circ} \mathrm{C}$; at $975^{\circ} \mathrm{C}$. for 14.5 hours the $\mathrm{C}$ phase was major with minor B phase. The C phase disappeared when the temperature was increased from $975^{\circ} \mathrm{C}$. to $1,120^{\circ} \mathrm{C}$. at $1 / 2^{\circ} \mathrm{C}$. per minute (the pattern at this temperature is given in table 16). 


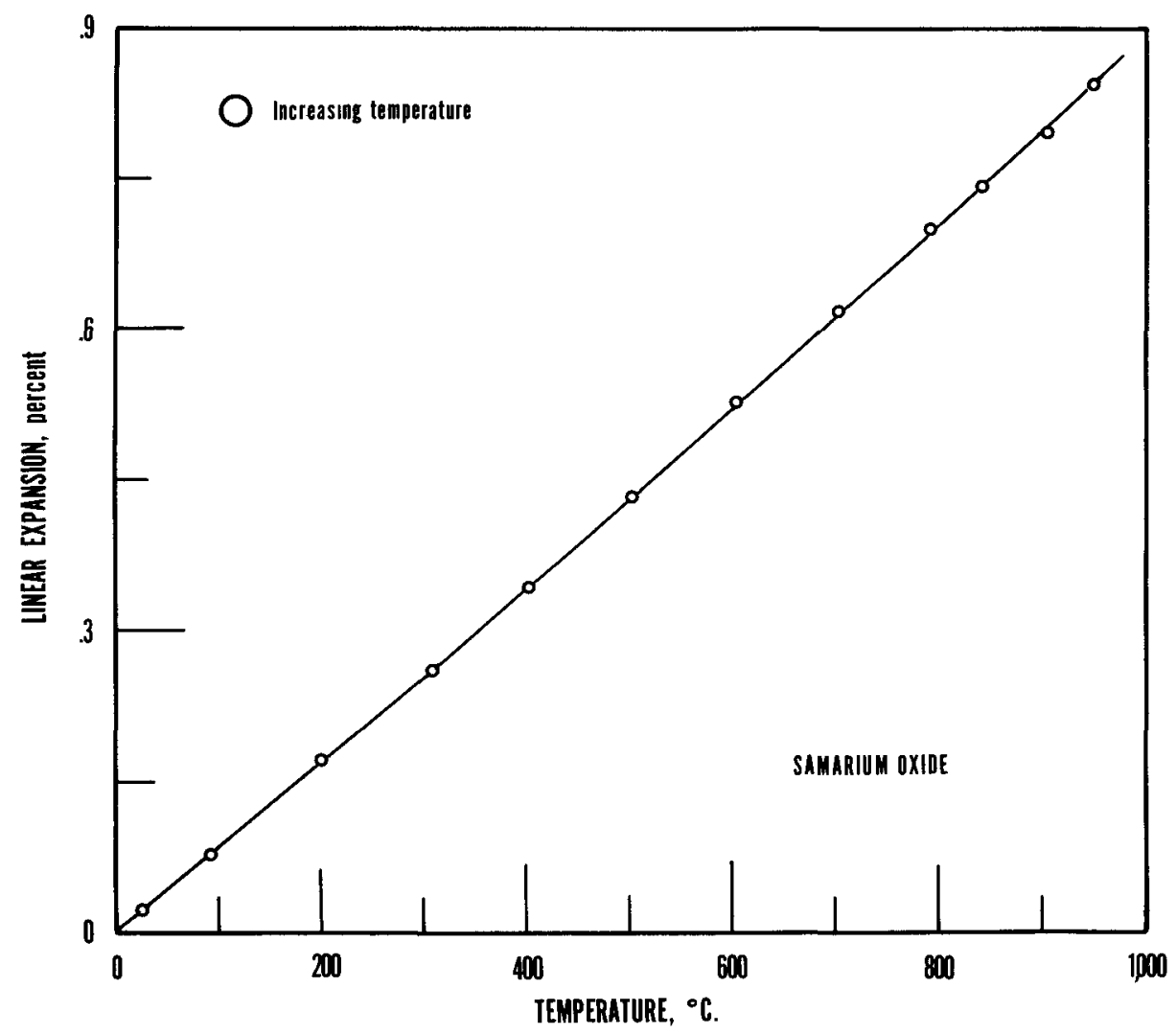

FIGURE 10. - Thermal Expansion of Samarium Sesquioxide.
Curtis (6) reported that the cubic phase disappeared above $1,100^{\circ} \mathrm{C}$.; Blum and Maguire (1) stated that $\mathrm{X}$-ray analysis indicated a phase change about $900^{\circ}$ C. The latter statement was in agreement with the authors' results.

Linear expansion coefficients of $9.9 \times 10^{-6}$ for $100^{\circ}$ to $1,000^{\circ} \mathrm{C}$. (6) and $10.8 \times 10^{-6}$ for $30^{\circ}$ to $740^{\circ} \mathrm{C}$. (15) were obtained on samples fired to $1,500^{\circ}$ and $1,800^{\circ} \mathrm{C}$. respectively. These temperatures give the $B$ phase only and therefore they do not agree with the results obtained in this investigation which was only concerned with the $C$ type.

TABLE 14. - Thermal expansion of samarium oxide

\begin{tabular}{|c|c|c|c|}
\hline $\begin{array}{c}\text { Temperature, } \\
\circ \mathrm{C} .\end{array}$ & $\begin{array}{l}\text { Unit ce11 } \\
\text { parameter, A }\end{array}$ & $\begin{array}{c}\text { Linear expansion, } \\
\text { percent }\end{array}$ & $\begin{array}{l}\text { Linear expansion } \\
\text { coefficient }\left(\times 10^{6}\right)\end{array}$ \\
\hline $\begin{array}{r}0 \ldots \ldots \ldots \ldots \\
26 \ldots \ldots \ldots \ldots \\
92 \ldots \ldots \ldots \ldots \\
200 \ldots \ldots \ldots \\
308 \ldots \ldots \ldots \\
403 \ldots \ldots \ldots \\
504 \ldots \ldots \ldots \\
604 \ldots \ldots \ldots \\
703 \ldots \ldots \ldots \\
792 \ldots \ldots \ldots \\
843 \ldots \ldots \ldots \\
905 \ldots \ldots \ldots \\
950 \ldots \ldots \ldots\end{array}$ & $\begin{array}{l}10.9085 \\
10.9109 \\
10.9170 \\
10.9271 \\
10.9369 \\
10.9459 \\
10.9558 \\
10.9660 \\
10.9759 \\
10.9850 \\
10.9896 \\
10.9953 \\
11.0006\end{array}$ & $\begin{array}{l}0.00 \\
.022 \\
.078 \\
.170 \\
.260 \\
.343 \\
.434 \\
.527 \\
.618 \\
.701 \\
.744 \\
.796 \\
.844\end{array}$ & $\begin{array}{l}7.5 \\
8.4 \\
8.5 \\
8.4 \\
8.5 \\
8.6 \\
8.7 \\
8.7 \\
8.8 \\
8.8 \\
8.8 \\
8.8\end{array}$ \\
\hline
\end{tabular}


TABLE 15. - Powder X-ray diffraction data for c-type samarium oxide at $25^{\circ} \mathrm{C}^{1}$

\begin{tabular}{l|c|c|c||c|c|c|c}
\hline hk1 & d-spacing, A & $\frac{I}{I_{100}} \times 100$ & $a, A$ & $h k 1$ & $d$-spacing, A & $\frac{I}{I_{100}} \times 100$ & $a, A$ \\
\hline 211 & 4.449 & 11 & 10.898 & 510 & 2.139 & 8 & 10.907 \\
222 & 3.146 & 100 & 10.900 & 440 & 1.928 & 33 & 10.905 \\
400 & 2.725 & 37 & 10.899 & 622 & 1.645 & 26 & 10.911 \\
331 & 2.502 & 3 & 10.906 & 444 & 1.574 & 7 & 10.906 \\
332 & 2.325 & 4 & 10.907 & & & & \\
\hline
\end{tabular}

${ }^{1}$ Fired at $820^{\circ} \mathrm{C}$. for 24 hours.

TABLE 16. - Powder X-ray diffraction data for samarium oxide at $1,122^{\circ} \mathrm{C}$.

\begin{tabular}{c|c||c|c}
\hline$d-$ spacing, $A$ & $\frac{I}{I_{100}} \times 100$ & $d$-spacing, $A$ & $\frac{I}{I_{100} \times 100}$ \\
\hline 3.455 & 27 & 2.185 & 37 \\
3.238 & 76 & 1.951 & 37 \\
3.078 & 73 & 1.851 & 25 \\
3.029 & 95 & 1.751 & 27 \\
2.930 & 51 & 1.678 & 29 \\
2.888 & 68 & 1.659 & 15 \\
2.868 & 100 & 1.573 & 15 \\
2.244 & 22 & & \\
\hline
\end{tabular}

Europium Oxide $\left(\mathrm{Eu}_{3} \mathrm{O}_{3}\right)$

Sample: Europium sesquioxide, supplied by Lindsay Chemical Co., West Chicago, I11. (their code 1011), was stated to be 99.9 percent $\mathrm{Eu}_{2} \mathrm{O}_{3}$ in regald to total rare-earth content. Optical spectrographic analyses (see table 2) indicated that the major non-rare-earth impurities were calcium, lead and silicon.

Sample Preparation: The sample was sintered at $1,000^{\circ} \mathrm{C}$. for 16 hours, packed into an alumina sample holder, sintered at $1,060^{\circ} \mathrm{C}$. for 12 hours, cooled to $300^{\circ} \mathrm{C}$. and placed in a vacuum desiccator for storage.

Method: The 222 and 622 lines were used for furnace alinement. Therma1 expansion was determined from the 622 line.

Results: See table 17 and figure 11.

Discussion: Europium sesquioxide is cubic at temperatures below $1,100^{\circ} \mathrm{C}$. (rare-earth oxide type $C$ ); lattice parameter of $10.886 \pm 0.005 \mathrm{~A}$, no temperature given (20). Curtis (7) found that the $C$ phase from europium oxalate decomposed at $800^{\circ} \mathrm{C}$. with a lattice parameter of $10.860 \pm 0.006 \mathrm{~A}$. Samples fired to $1,050^{\circ} \mathrm{C}$. for 60 hours were cubic only; at $1,100^{\circ} \mathrm{C}$. for 24 hours 
some transformation of $\mathrm{C}$ to $\mathrm{B}$ phase occurred. After 60 hours at $1,100^{\circ} \mathrm{C}$. this transformation was complete and at temperatures above $1,100^{\circ} \mathrm{C}$. only the $B$ form was observed. A sample fired at $1,050^{\circ} \mathrm{C}$. and indexed by the authors was found to contain only the cubic phase (see table 18).

Linear expansion coefficients of $10.3 \times 10^{-6}$ for $0^{\circ}$ to $1,200^{\circ} \mathrm{C}$. (7) and $10.5 \times 10^{-6}$ for $30^{\circ}$ to $850^{\circ} \mathrm{C}$. (15) were reported for samples fired to $1,500^{\circ}$ and $1,800^{\circ} \mathrm{C}$. respectively. At these temperatures only the monoclinic form (B type) would be present. The data obtained in this investigation is limited to the cubic phase; they are, therefore, not in agreement with the literature values. Ploetz and Krystyniak (14) reported bulk densities higher than theoretical densities on sintered compacts; their theoretical model was cubic, but their samples were sintered in the monoclinic region.

TABLE 17. - Thermal expansion of europium oxide

\begin{tabular}{|c|c|c|c|}
\hline $\begin{array}{c}\text { Temperature, } \\
{ }_{0} \text { C. }\end{array}$ & $\begin{array}{l}\text { Unit cell } \\
\text { parameter, A }\end{array}$ & $\begin{array}{c}\text { Linear expansion, } \\
\text { percent }\end{array}$ & $\begin{array}{l}\text { Linear expansion } \\
\text { coefficient }\left(x 10^{6}\right)\end{array}$ \\
\hline $\begin{array}{r}0 \ldots \ldots \ldots \ldots \\
26 \ldots \ldots \ldots \\
97 \ldots \ldots \ldots \\
211 \ldots \ldots \ldots \\
324 \ldots \ldots \ldots \\
403 \ldots \ldots \ldots \\
512 \ldots \ldots \ldots \\
635 \ldots \ldots \ldots \\
759 \ldots \ldots \ldots \\
887 \ldots \ldots \ldots \\
1,011 \ldots \ldots \ldots \\
1,129 \ldots \ldots \ldots \\
1,197 \ldots \ldots \ldots \\
1,261 \ldots \ldots \ldots\end{array}$ & $\begin{array}{l}10.8245 \\
10.8261 \\
10.8314 \\
10.8392 \\
10.8474 \\
10.8537 \\
10.8623 \\
10.8726 \\
10.8848 \\
10.8976 \\
10.9106 \\
10.9241 \\
10.9325 \\
10.9412\end{array}$ & $\begin{array}{l}0.00 \\
.015 \\
.064 \\
.136 \\
.212 \\
.270 \\
.349 \\
.444 \\
.557 \\
.675 \\
.795 \\
.920 \\
.998 \\
1.078\end{array}$ & $\begin{array}{l}5.7 \\
6.5 \\
6.4 \\
6.5 \\
6.6 \\
6.8 \\
6.9 \\
7.3 \\
7.6 \\
7.8 \\
8.1 \\
8.3 \\
8.5\end{array}$ \\
\hline
\end{tabular}

TABLE 18. - Powder X-ray diffraction data for europium oxide at $25^{\circ} \mathrm{C} .1$

\begin{tabular}{l|c|c|c||c|c|c|c}
\hline hk1 & d-spacing, A & $\frac{I}{I_{100}} \times 100$ & a, A & hk1 & $d$-spacing, A & $\frac{I}{I_{100} \times 100}$ & a, A \\
\hline 211 & 4.408 & 12 & 10.797 & 631 & 1.593 & 3 & 10.806 \\
222 & 3.115 & 100 & 10.791 & 444 & 1.560 & 4 & 10.807 \\
400 & 2.699 & 32 & 10.797 & 800 & 1.351 & 3 & 10.806 \\
411 & 2.546 & 5 & 10.802 & 811 & 1.330 & 3 & 10.807 \\
331 & 2.479 & 6 & 10.807 & 831 & 1.256 & 3 & 10.807 \\
332 & 2.304 & 5 & 10.805 & 662 & 1.240 & 6 & 10.806 \\
510 & 2.119 & 9 & 10.805 & 840 & 1.208 & 4 & 10.807 \\
440 & 1.910 & 39 & 10.806 & 844 & 1.103 & 3 & 10.807 \\
622 & 1.629 & 26 & 10.805 & & & & \\
\hline
\end{tabular}

${ }^{1}$ Fired at $980^{\circ} \mathrm{C}$. for 12 hours. 


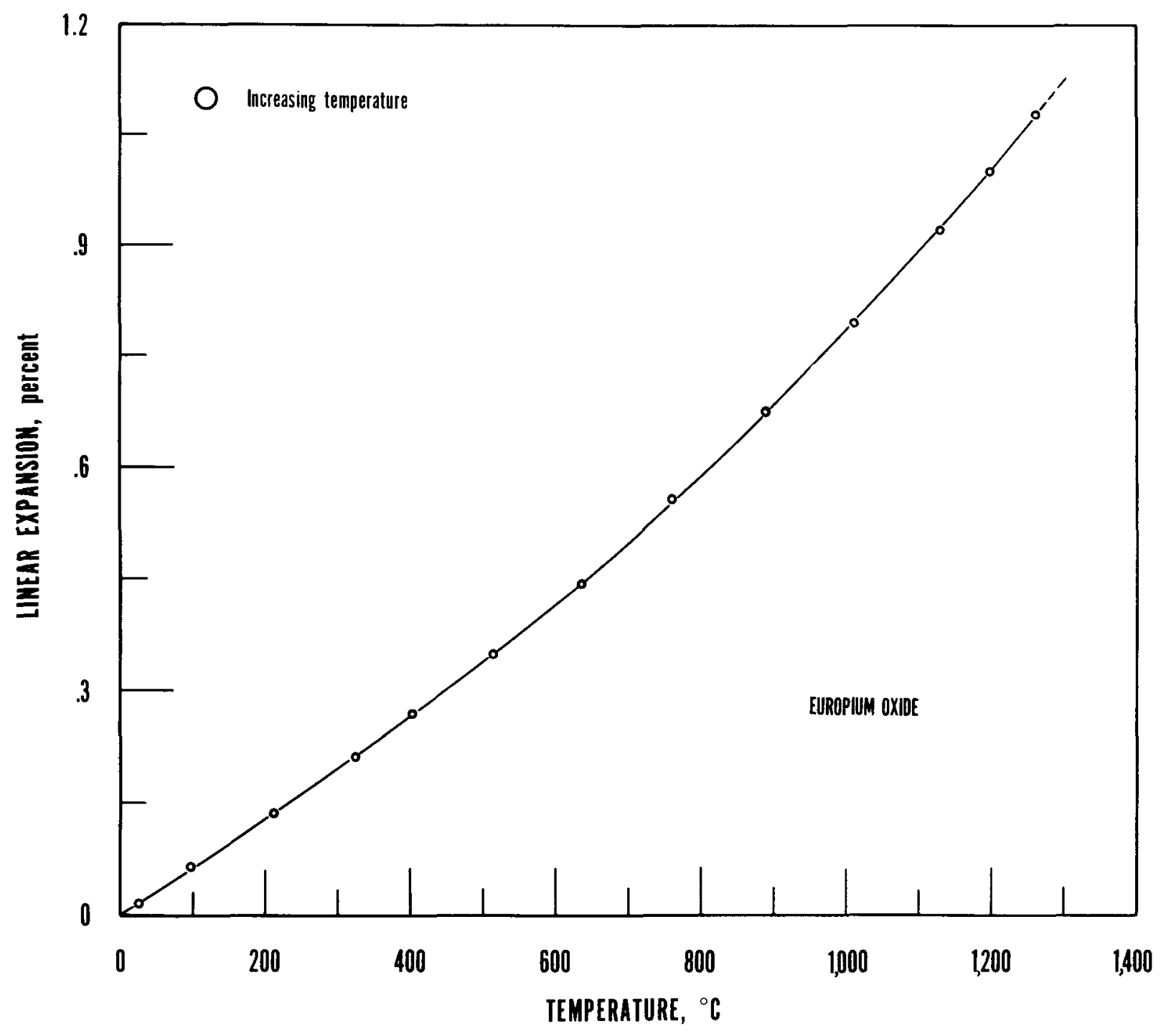

FIGURE 11. - Thermal Expansion of Europium Sesquioxide.

Gadolinium Oxide $\left(\mathrm{Gd}_{2} \mathrm{O}_{3}\right)$

Sample: Gadolinium sesquioxide, supplied by Michigan Chemical Co., St. Louis, Mich., was stated to be 99.9 percent $\mathrm{Gd}_{2} \mathrm{O}_{3}$ in regard to total rareearth content. Optical spectrographic analyses (see table 2) indicated that the major non-rare-earth impurities were calcium and silicon.

Sample Preparation: The sample was sintered at $1,150^{\circ} \mathrm{C}$. for 24 hours, packed into an alumina sample holder, sintered at $1,150^{\circ} \mathrm{C}$. for 12 hours, cooled to $350^{\circ} \mathrm{C}$. and placed in a vacuum desiccator for storage.

Method: The 222 and 662 lines were used for furnace alinement. Thermal expansion was determined from the 622 and 662 11nes; maximum deviation between values from both lines was less than \pm 2 percent above $500^{\circ} \mathrm{C}$. 
Results: See table 19 and figure 12 .

Discussion: Gadolinium sesquioxide is polymorphic; thermal expansion measurements are given for the cubic phase only in this report. Templeton and Dauben (20) reported a lattice parameter of $10.813 \pm 0.005 \mathrm{~A}$. The temperature at which this parameter is valid was not stated. Guentert and Mozzi (10) used high temperature diffraction techniques and found only C type oxide at $900^{\circ} \mathrm{C}$. in a 6-hour test, and in tests of $1,050^{\circ}$ and $1,200^{\circ} \mathrm{C}$. for $1 / 2$ hour each; at $1,400^{\circ} \mathrm{C}$. In a 1-hour test, two phases, B and $\mathrm{C}$, were found while at $1,600^{\circ} \mathrm{C}$. only the $B$ phase remained. The indexed B type (monoclinic) pattern is included in their report. Curtis (6) formed the B type from cubic $\mathrm{Gd}_{2} \mathrm{O}_{3}$ by firing it at $1,300^{\circ} \mathrm{C}$. The sample used for expansion studies was sintered at $1,250^{\circ} \mathrm{C}$. (maximum); only the cubic phase was observed. Although expansion measurements were obtained up to $1,310^{\circ} \mathrm{C}$. the sample was only at the maximum temperature for approximately one-half hour. The indexed pattern for the cubic system is given in table 20 .

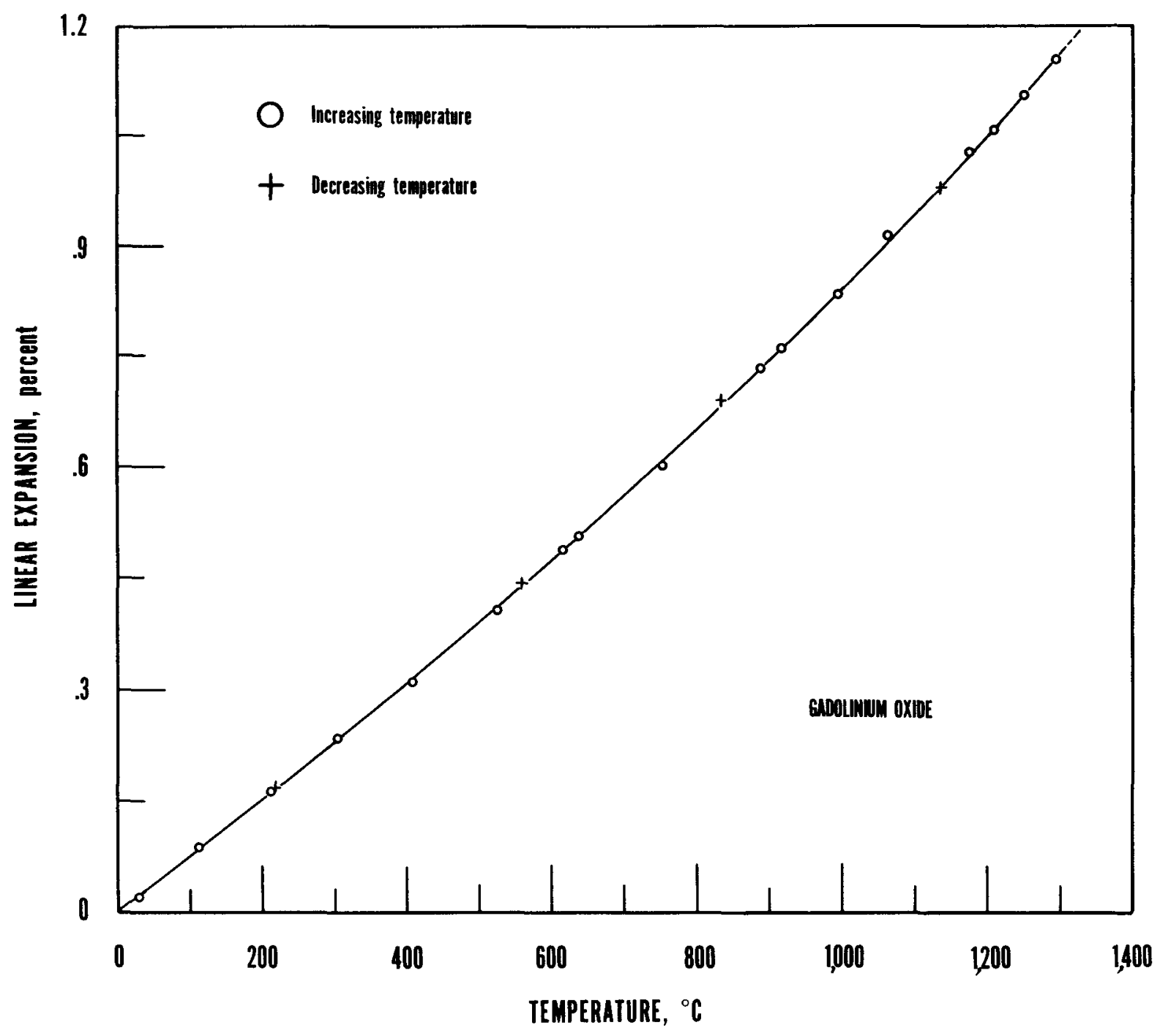

FIGURE 12. - Thermal Expansion of Gadolinium Sesquioxide. 
Linear expansion coefficients of $10.5 \times 10^{-6}$ for $100^{\circ}$ to $1,000^{\circ} \mathrm{C}$. (6) and $10.0 \times 10^{-6}$ for $30^{\circ}$ to $850^{\circ} \mathrm{C}$. (15) were obtained on samples fired to $1,500^{\circ}$ and $1,800^{\circ} \mathrm{C}$. respectively. In both cases the $\mathrm{B}$ phase would be the only phase present; therefore, the results would not be in agreement with those of the authors for the cubic phase.

TABLE 19. - Thermal expansion of gadolinium oxide

\begin{tabular}{|c|c|c|c|}
\hline $\begin{array}{c}\text { Temperature, } \\
\circ \mathrm{C} .\end{array}$ & $\begin{array}{l}\text { Unit cell } \\
\text { parameter, A }\end{array}$ & $\begin{array}{c}\text { Linear expansion, } \\
\text { percent }\end{array}$ & $\begin{array}{l}\text { Linear expansion } \\
\text { coefficient }\left(\times 10^{6}\right)\end{array}$ \\
\hline $0 \ldots \ldots$ & 10.7970 & 0.00 & \\
\hline $29 \ldots \ldots \ldots$ & 10.7992 & .020 & 6.8 \\
\hline $113 \ldots \ldots \ldots$ & 10.7964 & .087 & 7.6 \\
\hline $212 \ldots \ldots \ldots$ & 10.8146 & .163 & 7.6 \\
\hline $304 \ldots \ldots \ldots$ & 10.8223 & .234 & 7.6 \\
\hline $408 \ldots$ & 10.8306 & 311 & 7.6 \\
\hline $526 \ldots \ldots \ldots$ & 10.8408 & .406 & 7.7 \\
\hline $616 \ldots \ldots \ldots$ & 10.8497 & .488 & 7.9 \\
\hline $637 \ldots \ldots \ldots$ & 10.8517 & .507 & 7.9 \\
\hline $752 \ldots \ldots \ldots$ & 10.8619 & .601 & 7.9 \\
\hline $888 \ldots \ldots \ldots$ & 10.8761 & .733 & 8.2 \\
\hline $916 \ldots \ldots \ldots$ & 10.8792 & .761 & 8.3 \\
\hline $994 \ldots \ldots \ldots$ & 10.8870 & .834 & 8.3 \\
\hline $1,062 \ldots \ldots \ldots$ & 10.8959 & .916 & 8.6 \\
\hline $1,175 \ldots \ldots \ldots$ & 10.9081 & 1.029 & 8.7 \\
\hline $1,207 \ldots \ldots \ldots$ & 10.9113 & 1.059 & 8.7 \\
\hline $1,251 \ldots \ldots$ & 10.9164 & 1.106 & 8.8 \\
\hline $1,295 \ldots \ldots \ldots$ & 10.9215 & 1.153 & 8.9 \\
\hline $1,135 \ldots \ldots \ldots$ & 10.9029 & .981 & 8.6 \\
\hline $834 \ldots \ldots \ldots$ & 10.8715 & .690 & 8.2 \\
\hline $558 \ldots \ldots$ & 10.8447 & .442 & 7.9 \\
\hline $218 \ldots \ldots \ldots$ & 10.8153 & .170 & 7.7 \\
\hline
\end{tabular}

TABLE 20. - Powder X-ray diffraction data for gadolinium oxide at $25^{\circ} \mathrm{C},{ }^{2}$

\begin{tabular}{c|c|c|c||c|c|c|c}
\hline hk1 & $\begin{array}{c}\text { d-spacing, } \\
\text { A }\end{array}$ & $\frac{I}{I_{100}} \times 100$ & a, A & $h k 1$ & $\begin{array}{c}\text { d-spacing, } \\
\text { A }\end{array}$ & $\frac{I}{I_{100} \times 100}$ & $a, A$ \\
\hline 211 & 4.394 & 12 & 10.76 & 811 & 1.329 & 4 & 10.799 \\
222 & 3.108 & 100 & 10.768 & 831 & 1.256 & 8 & 10.802 \\
400 & 2.695 & 35 & 10.778 & 662 & 1.239 & 8 & 10.803 \\
411 & 2.541 & 7 & 10.781 & 840 & 1.208 & 7 & 10.801 \\
331 & 2.476 & 3 & 10.794 & 851 & 1.139 & 2 & 10.804 \\
332 & 2.299 & 4 & 10.783 & 844 & 1.103 & 5 & 10.805 \\
431 & 2.115 & 10 & 10.785 & 10.2 .0 & 1.0597 & 2 & 10.8069 \\
440 & 1.907 & 43 & 10.790 & 10.2 .2 & 1.0400 & 2 & 10.8080 \\
611 & 1.751 & 5 & 10.793 & 10.3 .1 & 1.0303 & 3 & 10.8069 \\
622 & 1.623 & 31 & 10.795 & 871 & 1.0122 & 2 & 10.8073 \\
631 & 1.592 & 7 & 10.794 & $10.4 \cdot 0$ & 1.0034 & 3 & 10.8059 \\
444 & 1.559 & 7 & 10.799 & $10.4 \cdot 2$ & 0.9867 & 3 & 10.8084 \\
721 & 1.470 & 4 & 10.799 & 11.2 .1 & 0.9630 & 3 & 10.8096 \\
800 & 1.350 & 4 & 10.799 & 10.6 .2 & 0.9136 & 4 & 10.8094 \\
\hline
\end{tabular}

IFired at $1,070^{\circ} \mathrm{C}$. for 24 hours. 


\section{Dysprosium Oxide $\left(\mathrm{Dy}_{2} \mathrm{O}_{3}\right)$}

Sample: Dysprosium sesquioxide, supplied by Michigan Chemical Corp., St. Louis, Mich., was stated to be 99 percent $\mathrm{Dy}_{2} \mathrm{O}_{3}$ in regard to total rareearth content. Optical spectrographic analyses (see table 2) indicated that the major non-rare-earth impurities were calcium and magnesium.

Sample Preparation: The sample was sintered at $1,150^{\circ} \mathrm{C}$. for 24 hours, packed into an alumina sample holder, sintered at $1,150^{\circ} \mathrm{C}$, cooled to $350^{\circ} \mathrm{C}$. and placed in a vacuum desiccator for storage.

Method: The 222 and 840 lines were used for furnace alinement. Thermal expansion was determined from the 622 and 840 lines. Thermal expansion values from both lines agreed to within \pm 2 percent above $500^{\circ} \mathrm{C}$.

Results: See table 21 and figure 13.

TABLE 21. - Thermal expansion of dysprosium oxide

\begin{tabular}{|c|c|c|c|}
\hline $\begin{array}{c}\text { Temperature, } \\
\circ \mathrm{C} . \\
\end{array}$ & $\begin{array}{l}\text { Unit cell } \\
\text { parameter, A }\end{array}$ & $\begin{array}{c}\text { Linear expansion, } \\
\text { percent }\end{array}$ & $\begin{array}{l}\text { Linear expansion } \\
\text { coefficient }\left(x 10^{6}\right)\end{array}$ \\
\hline $\begin{array}{r}0 \ldots \ldots \ldots \\
27 \ldots \ldots \ldots \\
120 \ldots \ldots \ldots \\
185 \ldots \ldots \ldots \\
255 \ldots \ldots \ldots \\
352 \ldots \ldots \ldots \\
476 \ldots \ldots \\
546 \ldots \ldots \\
597 \ldots \ldots \\
730 \ldots \ldots \\
852 \ldots \ldots \\
858 \ldots \ldots \\
955 \ldots \ldots \\
985 \ldots \ldots \\
1,054 \ldots \ldots \\
1,165 \ldots \ldots \\
1,207 \ldots \ldots \\
1, \ldots \ldots \\
1,256 \ldots \ldots \\
1,155 \ldots \ldots \\
151 \ldots \ldots \ldots \\
913 \ldots \ldots \\
647 \ldots \ldots \ldots \\
426 \ldots \ldots \\
219 \ldots \ldots \\
93 \ldots \ldots \ldots\end{array}$ & $\begin{array}{l}10.6530 \\
10.6542 \\
10.6625 \\
10.6678 \\
10.6732 \\
10.6817 \\
10.6924 \\
10.6987 \\
10.7027 \\
10.7152 \\
10.7269 \\
10.7277 \\
10.7376 \\
10.7396 \\
10.7472 \\
10.7595 \\
10.7640 \\
10.7702 \\
10.7740 \\
10.7581 \\
10.7331 \\
10.7076 \\
10.6879 \\
10.6707 \\
10.6600\end{array}$ & $\begin{array}{l}0.00 \\
.018 \\
.080 \\
.139 \\
.190 \\
.269 \\
.361 \\
.429 \\
.467 \\
.584 \\
.694 \\
.701 \\
.794 \\
.813 \\
.884 \\
1.000 \\
1.042 \\
1.100 \\
1.136 \\
.987 \\
.752 \\
.513 \\
.328 \\
.166 \\
.066\end{array}$ & $\begin{array}{l}6.6 \\
6.6 \\
7.5 \\
7.4 \\
7.6 \\
7.5 \\
7.8 \\
7.8 \\
8.0 \\
8.1 \\
8.1 \\
8.3 \\
8.2 \\
8.3 \\
8.5 \\
8.6 \\
8.7 \\
8.8 \\
8.5 \\
8.2 \\
7.9 \\
7.6 \\
7.5 \\
7.0\end{array}$ \\
\hline
\end{tabular}


Discussion: Dysprosium sesquioxide is cubic with thallium oxide type structure (rare-earth oxide type C) and $12 \mathrm{Dy}_{2} \mathrm{O}_{3}$ per unit ce11; lattice constant at $25^{\circ} \mathrm{C}$. is $10.665 \mathrm{~A}(19$, vol. 9,1960 , pp. 30-31). No phase inversion was observed over the temperature range covered $\left(25^{\circ}\right.$ to $\left.1,300^{\circ} \mathrm{C}.\right)$. Staritzky (17) reported cubic $\mathrm{Dy}_{3} \mathrm{O}_{3}$ to be crystallized from the melt. When the authors' study on $\mathrm{Dy}_{2} \mathrm{O}_{3}$ was undertaken, the National Bureau of Standards data had not been published; indexing of the powder pattern by the authors is in good agreement with the recent NBS publication (19).

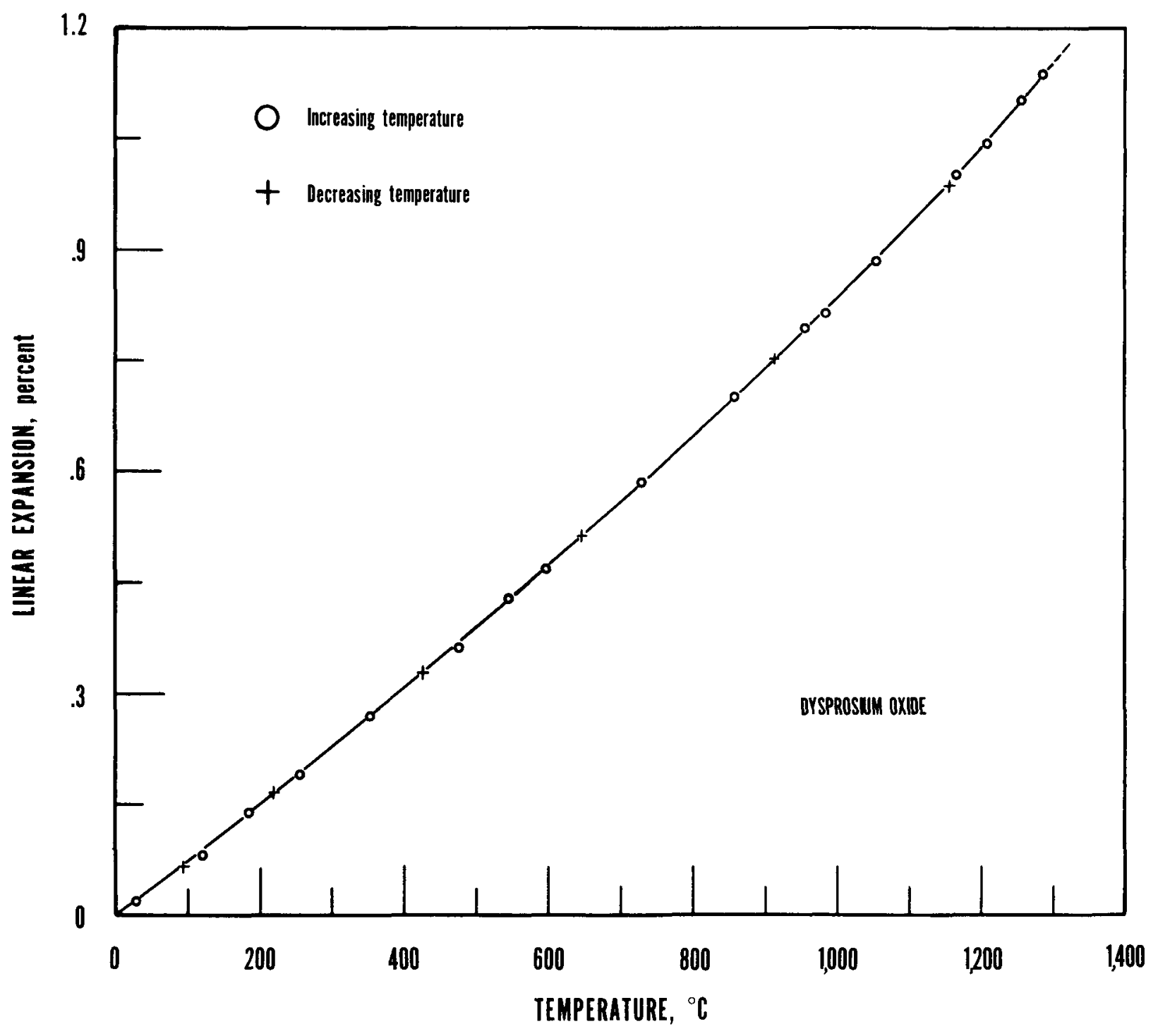

FIGURE 13. - Thermal Expansion of Dysprosium Sesquioxide. 
Holmium Oxide $\left(\mathrm{Ho}_{2} \mathrm{O}_{3}\right)$

Sample: Holmium sesquioxide, supplied by Michigan Chemical Co., St. Louis, Mich., was stated to be 99.9 percent $\mathrm{Ho}_{2} \mathrm{O}_{3}$ in regard to total rareearth content. Optical spectrographic analyses (see table 2) indicated that the major non-rare-earth impurities were calcium, magnesium, and silicon.

Sample Preparation: The sample was sintered at $1,300^{\circ} \mathrm{C}$. for 24 hours, packed into an alumina sample holder, sintered at $1,300^{\circ} \mathrm{C}$. for 24 hours, cooled to $200^{\circ} \mathrm{C}$. and placed in a vacuum desiccator for storage.

Method: The 222 and 844 lines were used for furnace alinement. Thermal expansion was determined from the 844 and 12.4.2 lines; maximum deviation between values obtained from both lines was less than \pm 2 percent above $500^{\circ} \mathrm{C}$.

Results: See table 22 and figure 14.

Discussion: Holmium sesquioxide $\left(\mathrm{Ho}_{2} \mathrm{O}_{3}\right)$ is cubic with the thallium oxide type structure (rare-earth oxide type C) with $16 \mathrm{H}_{2} \mathrm{O}_{3}$ per unit cell; lattice parameter at $25^{\circ} \mathrm{C}$. is $10.606 \mathrm{~A}$. (19, vol. 9, 1960, pp. 32-33). No phase inversion was observed over the temperature range covered $\left(25^{\circ}\right.$ to $1,300^{\circ} \mathrm{C}$.).

TABLE 22. - Thermal expansion of holmium oxide

\begin{tabular}{|c|c|c|c|}
\hline $\begin{array}{c}\text { Temperature, } \\
\circ \mathrm{C} . \\
\end{array}$ & $\begin{array}{l}\text { Unit ce } 11 \\
\text { parameter, A }\end{array}$ & $\begin{array}{c}\text { Linear expansion, } \\
\text { percent }\end{array}$ & $\begin{array}{l}\text { Linear expansion } \\
\text { coefficient }\left(\times 10^{6}\right)\end{array}$ \\
\hline $0 \ldots \ldots \ldots$ & 10.6060 & 0.00 & \\
\hline $26 \ldots \ldots \ldots$ & 10.6080 & .019 & 7.2 \\
\hline $108 \ldots \ldots \ldots$ & 10.6144 & .079 & 7.3 \\
\hline $152 \ldots \ldots \ldots$ & 10.6180 & .113 & 7.4 \\
\hline $255 \ldots \ldots \ldots$ & 10.6264 & .192 & 7.5 \\
\hline $333 \ldots \ldots$ & 10.6334 & .258 & 7.7 \\
\hline $438 \ldots \ldots \ldots$ & 10.6422 & .342 & 7.8 \\
\hline $500 \ldots \ldots \ldots$ & 10.6473 & .389 & 7.7 \\
\hline $616 \ldots \ldots \ldots$ & 10.6577 & .488 & 7.9 \\
\hline $675 \ldots \ldots$ & 10.6630 & .541 & 8.0 \\
\hline $712 \ldots \ldots$ & 10.6665 & .570 & 8.0 \\
\hline $860 \ldots \ldots$ & 10.6803 & .701 & 8.1 \\
\hline $969 \ldots \ldots \ldots$ & 10.6910 & .802 & 8.2 \\
\hline $1,070 \ldots \ldots \ldots$ & 10.7018 & .903 & 8.4 \\
\hline $1,147 \ldots \ldots$ & 10.7098 & .979 & 8.5 \\
\hline $1,207 \ldots \ldots \ldots$ & 10.7160 & 1.037 & 8.5 \\
\hline $1,225 \ldots \ldots \ldots$ & 10.7178 & 1.054 & 8.6 \\
\hline $1,295 \ldots \ldots \ldots$ & 10.7250 & 1.122 & 8.6 \\
\hline $1,073 \ldots \ldots \ldots$ & 10.7018 & .903 & 8.4 \\
\hline $754 \ldots \ldots$ & 10.6704 & .607 & 8.0 \\
\hline $642 \ldots \ldots \ldots$ & 10.6606 & .515 & 8.0 \\
\hline $274 \ldots \ldots \ldots$ & 10.6283 & .211 & 7.6 \\
\hline
\end{tabular}




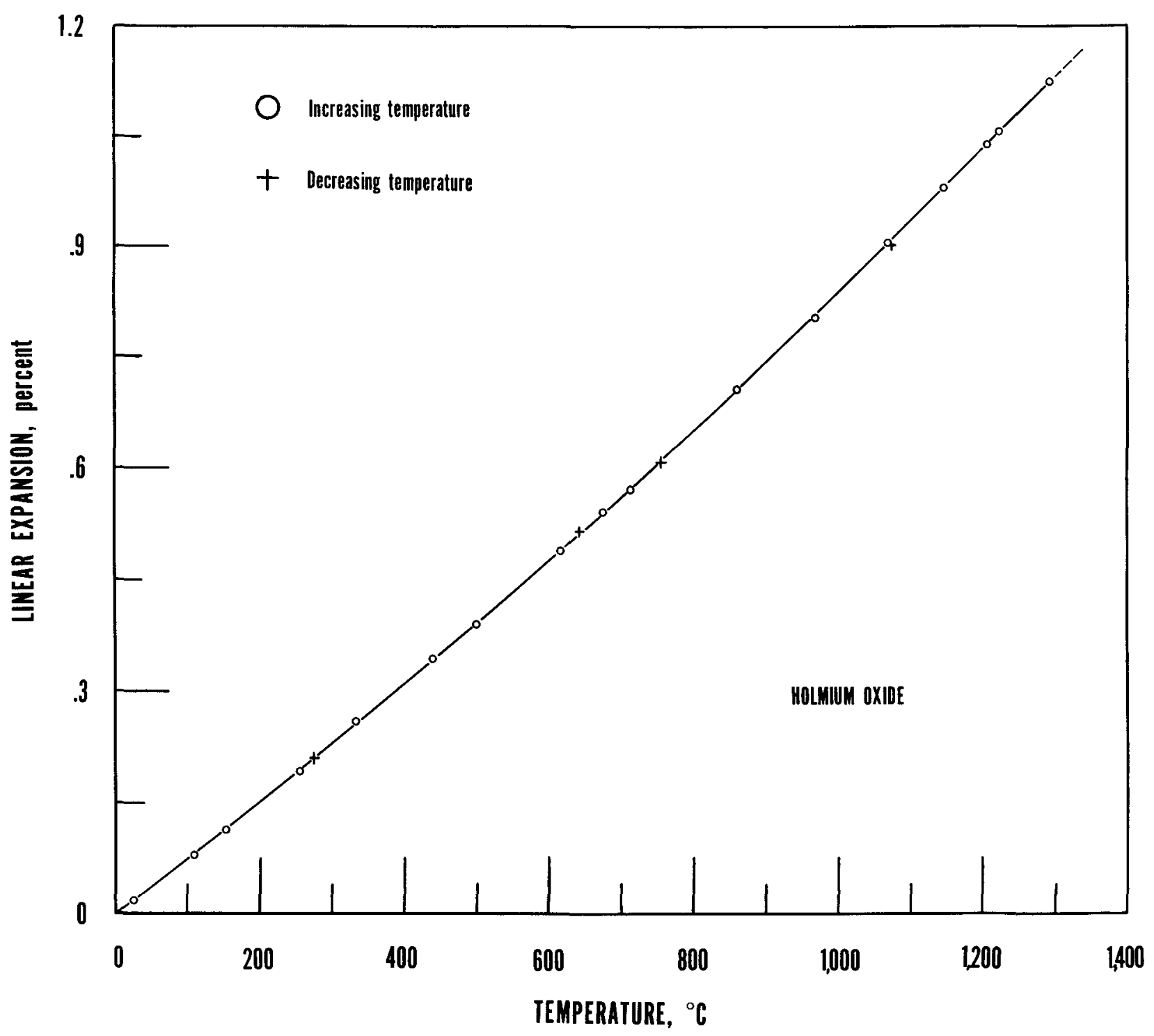

FIGURE 14. - Thermal Expansion of Holmium Sesquioxide.

$$
\text { Erbium Oxide }\left(\operatorname{Er}_{2} 0_{3}\right)
$$

Sample: Erbium sesquioxide, supplied by Lindsay Chemical Co., West Chicago, I11. (their code 1305), was stated to be 99.9 percent $\mathrm{Er}_{2} \mathrm{O}_{3}$ in regard to total rare-earth content. Optical spectrographic analyses (see table 2) indicated that the major non-rare-earth impurity was calcium.

Sample Preparation: The sample was sintered at $1,300^{\circ} \mathrm{C}$. for 24 hours, packed into an alumina holder, sintered at $1,350^{\circ} \mathrm{C}$. for 12 hours, cooled to $300^{\circ} \mathrm{C}$. and placed in a vacuum desiccator for storage. 
Method: The 222 and 12.2.1 lines were used for furnace alinement. Thermal expansion was determined from the 10.6 .2 and 12.2 .1 lines. Thermal expansion values from both lines agreed to within \pm 2 percent above $500^{\circ} \mathrm{C}$.

Results: See table 23 and figure 15.

Discussion: Erbium sesquioxide is cubic with thallium oxide type structure (rare-earth oxide type C) and $16 \mathrm{Er}_{2} \mathrm{O}_{3}$ per unit ce11; lattice constant at $27^{\circ} \mathrm{C}$. is $10.548 \mathrm{~A}(19$, vol. 8, 1959, pp. 25-27). No phase inversion was observed over temperature range studied $\left(25^{\circ}\right.$ to $1,300^{\circ} \mathrm{C}$.). Staritzky (17) reported cubic $\mathrm{Er}_{3} \mathrm{O}_{3}$ to be crystallized from the melt.

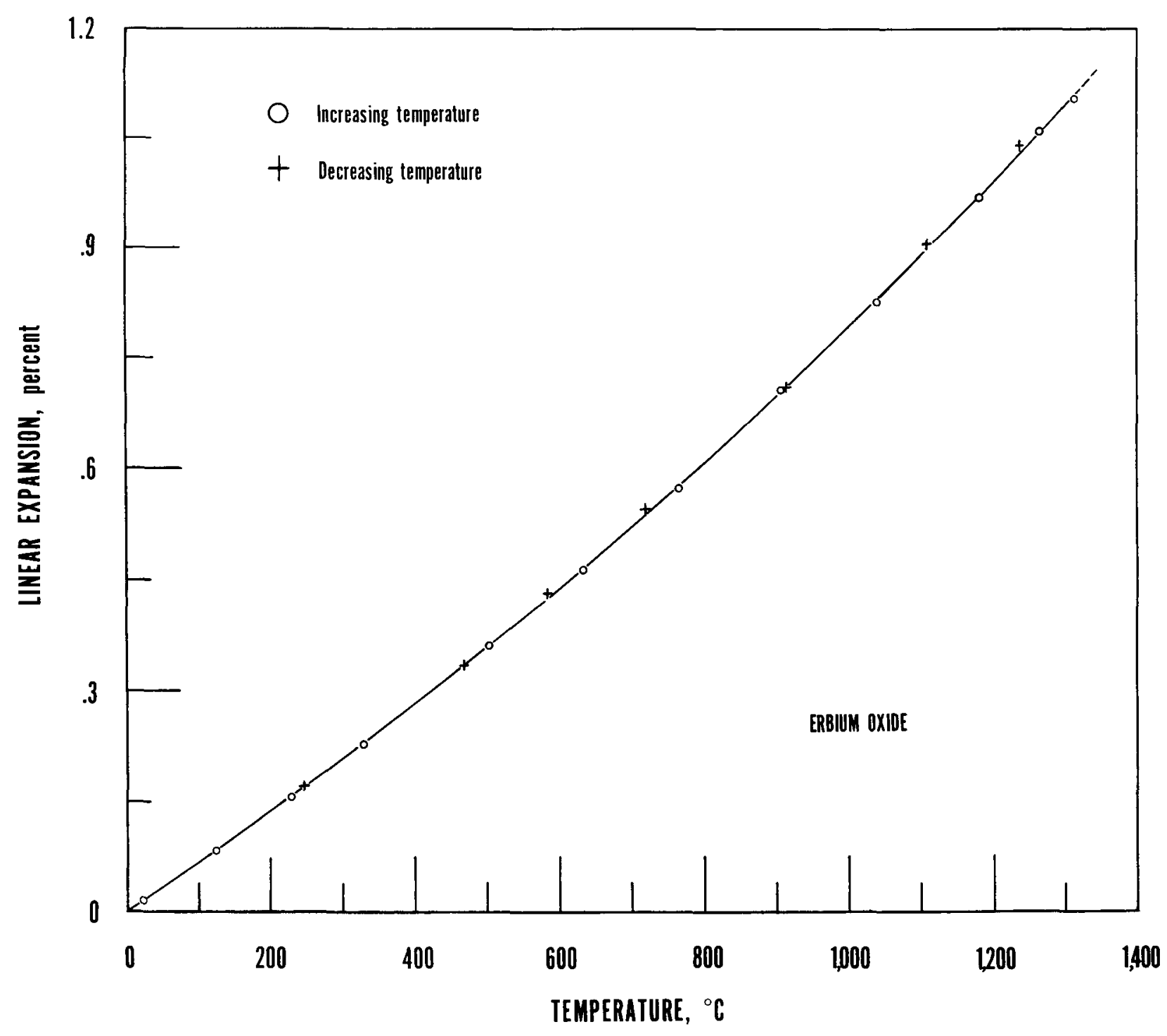

FIGURE 15. - Thermal Expansion of Erbium Sesquioxide. 
TABLE 23. - Thermal expansion of erbium oxide

\begin{tabular}{|c|c|c|c|}
\hline $\begin{array}{c}\text { Temperature, } \\
\circ \mathrm{C} .\end{array}$ & $\begin{array}{c}\text { Unit cel1 } \\
\text { parameter, A }\end{array}$ & $\begin{array}{c}\text { Linear expansion, } \\
\text { percent }\end{array}$ & $\begin{array}{l}\text { Linear expansion } \\
\text { coefficient }\left(x 10^{6}\right)\end{array}$ \\
\hline $0 \ldots \ldots \ldots$ & 10.5450 & 0.00 & \\
\hline $23 \ldots \ldots \ldots$ & 10.5465 & .014 & 6.0 \\
\hline $125 \ldots \ldots$ & 10.5538 & .083 & 6.6 \\
\hline $229 \ldots \ldots \ldots$ & 10.5613 & .155 & 6.7 \\
\hline $328 \ldots \ldots \ldots$ & 10.5690 & .230 & 6.9 \\
\hline $502 \ldots \ldots \ldots$ & 10.5829 & .360 & 7.1 \\
\hline $633 \ldots \ldots \ldots$ & 10.5938 & .463 & 7.3 \\
\hline $765 \ldots \ldots$ & 10.6054 & .573 & 7.4 \\
\hline $906 \ldots$ & 10.6194 & .706 & 7.7 \\
\hline $1,038 \ldots$ & 10.6322 & .827 & 7.9 \\
\hline $1,181 \ldots \ldots \ldots$ & 10.6472 & .969 & 8.2 \\
\hline $1,264 \ldots \ldots \ldots$ & 10.6569 & 1.061 & 8.3 \\
\hline $1,312 \ldots$ & 10.6613 & 1.103 & 8.4 \\
\hline $1,238 \ldots \ldots \ldots$ & 10.6542 & 1.036 & 8.3 \\
\hline $1,110 \ldots \ldots \ldots$ & 10.6403 & .905 & 8.1 \\
\hline $913 \ldots \ldots \ldots$ & 10.6199 & .710 & 7.7 \\
\hline $720 \ldots$ & 10.6026 & .546 & 7.5 \\
\hline $582 \ldots \ldots \ldots$ & 10.5903 & .430 & 7.3 \\
\hline $467 \ldots$ & 10.5802 & .334 & 7.1 \\
\hline $248 \ldots \ldots \ldots$ & 10.5629 & .170 & 6.8 \\
\hline
\end{tabular}

Thulium Oxide $\left(\mathrm{Tm}_{2} \mathrm{O}_{3}\right)$

Sample: Thulium sesquioxide, supplied by Lindsay Chemical Co., West Chicago, II1. (their code 1405), was stated to be $99.9 \operatorname{Tm}_{2} \mathrm{O}_{3}$ in regard to total rare-earth content. Optical spectrographic analyses (see table 2) indicated that the major non-rare-earth impurities were calcium and silicon.

Sample Preparation: The sample was sintered at $1,200^{\circ} \mathrm{C}$. for 24 hours, packed into an alumina sample holder, sintered at $1,300^{\circ} \mathrm{C}$. for 12 hours, cooled to $400^{\circ} \mathrm{C}$. and placed in a vacuum desiccator for storage.

Method: The 222 and 12.4.2 lines were used for furnace alinement. Thermal expansion was determined from the 10.6.2 and 12.4.2 lines; maximum deviation between values from both lines was less than \pm 2 percent above $500^{\circ} \mathrm{C}$.

Results: See table 24 and figure 16.

Discussion: Thulium sesquioxide is cubic with a thallium oxide type structure (rare-earth oxide type $C$ ) and $16 \mathrm{Tm}_{2} \mathrm{O}_{3}$ per unit cell; lattice constant at $25^{\circ} \mathrm{C}$. is $10.488 \mathrm{~A}(19$, vol. 9, 1960, pp. 58-59). No phase inversion was observed over the temperature range covered $\left(25^{\circ}\right.$ to $\left.1,300^{\circ} \mathrm{C}.\right)$. At the time of this investigation the National Bureau of Standards data had not been published. The indexing of the powder diffraction data by the authors is in agreement with the recent publication (19). 


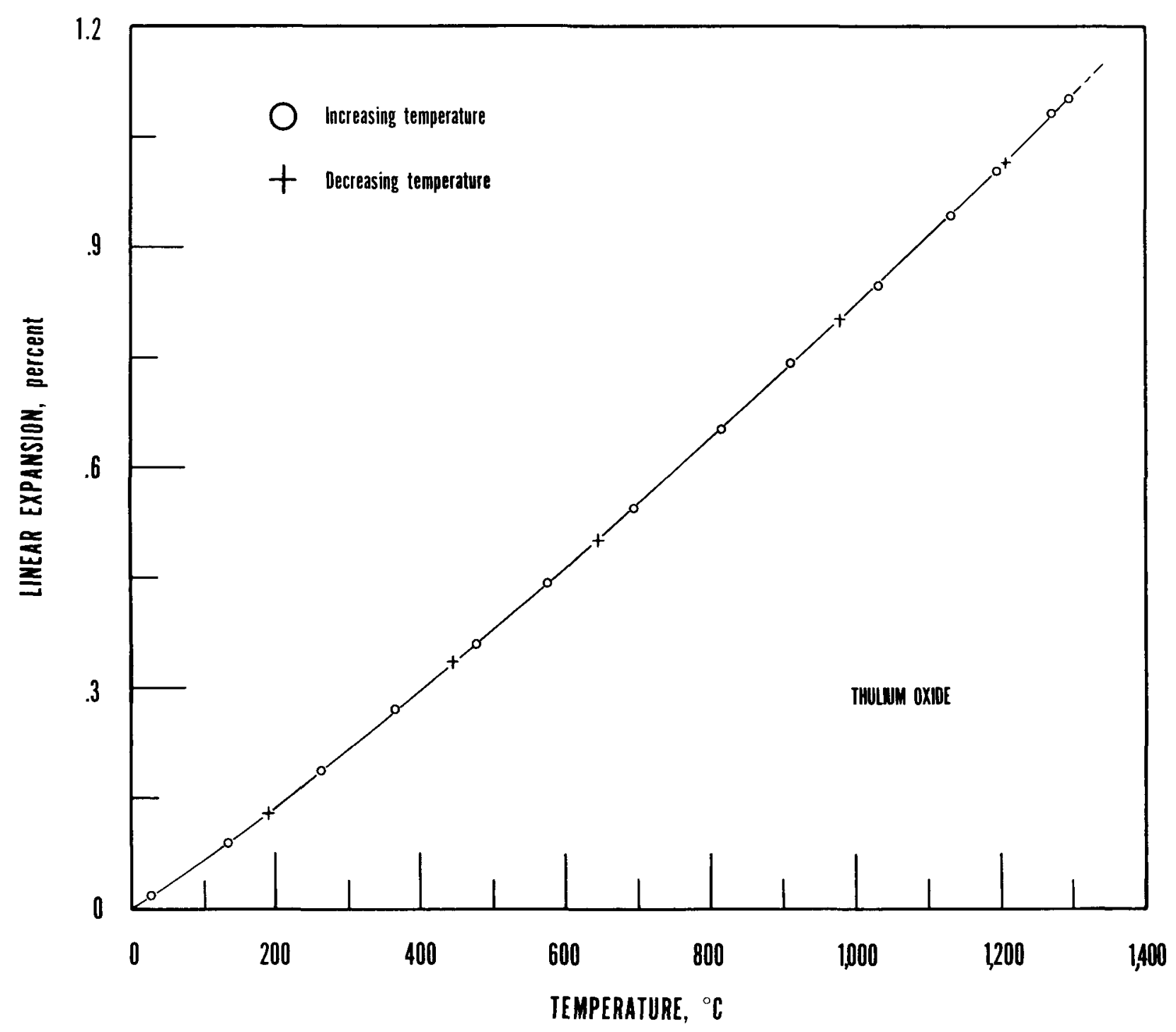

FIGURE 16. - Thermal Expansion of Thulium Sesquioxide.

Ytterbium Oxide $\left(\mathrm{Yb}_{2} \mathrm{O}_{3}\right)$

Sample: Ytterbium oxide, supplied by Michigan Chemical Co., St. Louis, Mich., was stated to be 99.9 percent $\mathrm{Yb}_{2} \mathrm{O}_{3}$ in regard to rare-earth content. Optical spectrographic analyses (see table 2) indicated that the major nonrare earth impurities were calcium and silicon.

Sample Preparation: The sample was sintered at $1,300^{\circ} \mathrm{C}$. for 24 hours, packed into an alumina sample holder, sintered at $1,400^{\circ} \mathrm{C}$. for 12 hours, cooled to $250^{\circ} \mathrm{C}$. and placed in a vacuum desiccator for storage. 
TABLE 24. - Thermal expansion of thulium oxide

\begin{tabular}{|c|c|c|c|}
\hline $\begin{array}{c}\text { Temperature, } \\
0 \mathrm{C} . \\
\end{array}$ & $\begin{array}{l}\text { Unit ce } 11 \\
\text { parameter, A }\end{array}$ & $\begin{array}{c}\text { Linear expansion, } \\
\text { percent }\end{array}$ & $\begin{array}{l}\text { Linear expansion } \\
\text { coefficient }\left(x \quad 10^{6}\right)\end{array}$ \\
\hline $0 \ldots \ldots \ldots$ & 10.4843 & 0.00 & \\
\hline $28 \ldots \ldots \ldots$ & 10.4863 & .019 & 6.8 \\
\hline $134 \ldots \ldots \ldots$ & 10.4937 & .090 & 6.6 \\
\hline $264 \ldots \ldots \ldots$ & 10.5041 & .189 & 7.1 \\
\hline $364 \ldots \ldots \ldots$ & 10.5128 & .272 & 7.4 \\
\hline $477 \ldots \ldots \ldots$ & 10.5220 & .360 & 7.5 \\
\hline $575 \ldots \ldots$ & 10.5308 & .444 & 7.7 \\
\hline $695 \ldots \ldots \ldots$ & 10.5415 & .546 & 7.8 \\
\hline $814 \ldots \ldots \ldots$ & 10.5527 & .652 & 8.0 \\
\hline $911 \ldots \ldots \ldots$ & 10.5622 & .743 & 8.1 \\
\hline $1,031 \ldots \ldots \ldots$ & 10.5733 & .849 & 8.2 \\
\hline $1,132 \ldots \ldots \ldots$ & 10.5832 & .943 & 8.3 \\
\hline $1,196 \ldots \ldots \ldots$ & 10.5897 & 1.005 & 8.4 \\
\hline $1,271 \ldots \ldots \ldots$ & 10,5979 & 1.084 & 8.5 \\
\hline $1,295 \ldots \ldots \ldots$ & 10.6000 & 1.104 & 8.5 \\
\hline $1,206 \ldots \ldots \ldots$ & 10.5908 & 1.016 & 8.4 \\
\hline $978 \ldots \ldots$ & 10.5685 & .803 & 8.2 \\
\hline $646 \ldots \ldots \ldots$ & 10.5368 & .501 & 7.7 \\
\hline $445 \ldots \ldots \ldots$ & 10.5195 & .336 & 7.5 \\
\hline $190 \ldots \ldots \ldots$ & 10.4978 & .129 & 6.7 \\
\hline
\end{tabular}

Method: The 222 and 12.4.2 lines were used for furnace alinement. Thermal expansion was determined from the 10.6.2 and 12.4 .2 1ines; maximum deviation between values from both lines was less than \pm 2 percent above $500^{\circ} \mathrm{C}$.

Results: See table 25 and figure 17.

TABLE 25. - Thermal expansion of ytterbium oxide

\begin{tabular}{|c|c|c|c|}
\hline $\begin{array}{c}\text { Temperature, } \\
\circ \mathrm{C} .\end{array}$ & $\begin{array}{c}\text { Unit cell } \\
\text { parameter, A }\end{array}$ & $\begin{array}{c}\text { Linear expansion, } \\
\text { percent }\end{array}$ & $\begin{array}{l}\text { Linear expansion } \\
\text { coefficient }\left(\times 10^{6}\right)\end{array}$ \\
\hline $0 \ldots \ldots$ & 10.4325 & 0.00 & \\
\hline $26 \ldots \ldots$ & 10.4343 & .017 & 6.5 \\
\hline $158 \ldots \ldots \ldots$ & 10.4438 & .108 & 6.8 \\
\hline $280 \ldots \ldots \ldots$ & 10.4534 & .200 & 7.1 \\
\hline $401 \ldots \ldots \ldots$ & 10.4632 & .294 & 7.3 \\
\hline $516 \ldots \ldots \ldots$ & 10.4730 & .388 & 7.5 \\
\hline $634 \ldots \ldots \ldots$ & 10.4837 & .491 & 7.7 \\
\hline $760 \ldots \ldots$ & 10.4948 & .597 & 7.8 \\
\hline $884 \ldots \ldots \ldots$ & 10.5065 & .710 & 8.0 \\
\hline $1,021 \ldots \ldots \ldots$ & 10.5194 & .833 & 8.1 \\
\hline $1,102 \ldots$ & 10.5263 & .903 & 8.2 \\
\hline $1,242 \ldots \ldots \ldots$ & 10.5415 & 1.044 & 8.4 \\
\hline $1,293 \ldots \ldots \ldots$ & 10.5468 & 1.096 & 8.4 \\
\hline $1,138 \ldots \ldots \ldots$ & 10.5305 & .939 & 8.2 \\
\hline $927 \ldots \ldots \ldots$ & 10.5106 & .749 & 8.0 \\
\hline $700 \ldots \ldots$ & 10.4897 & .547 & 7.8 \\
\hline
\end{tabular}


Discussion: Ytterbium sesquioxide is cubic (rare-earth oxide type C) with $16 \mathrm{Yb}_{2} \mathrm{O}_{3}$ per unit ce11, the lattice parameter is $10.435 \pm 0.001 \mathrm{~A}$, at an unstated temperature (17). The indexed powder pattern (see table 26) is included in this report because these data are not available in the ASTM diffraction card system. No phase inversion was observed over the temperature range covered $\left(25^{\circ}\right.$ to $\left.1,350^{\circ} \mathrm{C}.\right)$.

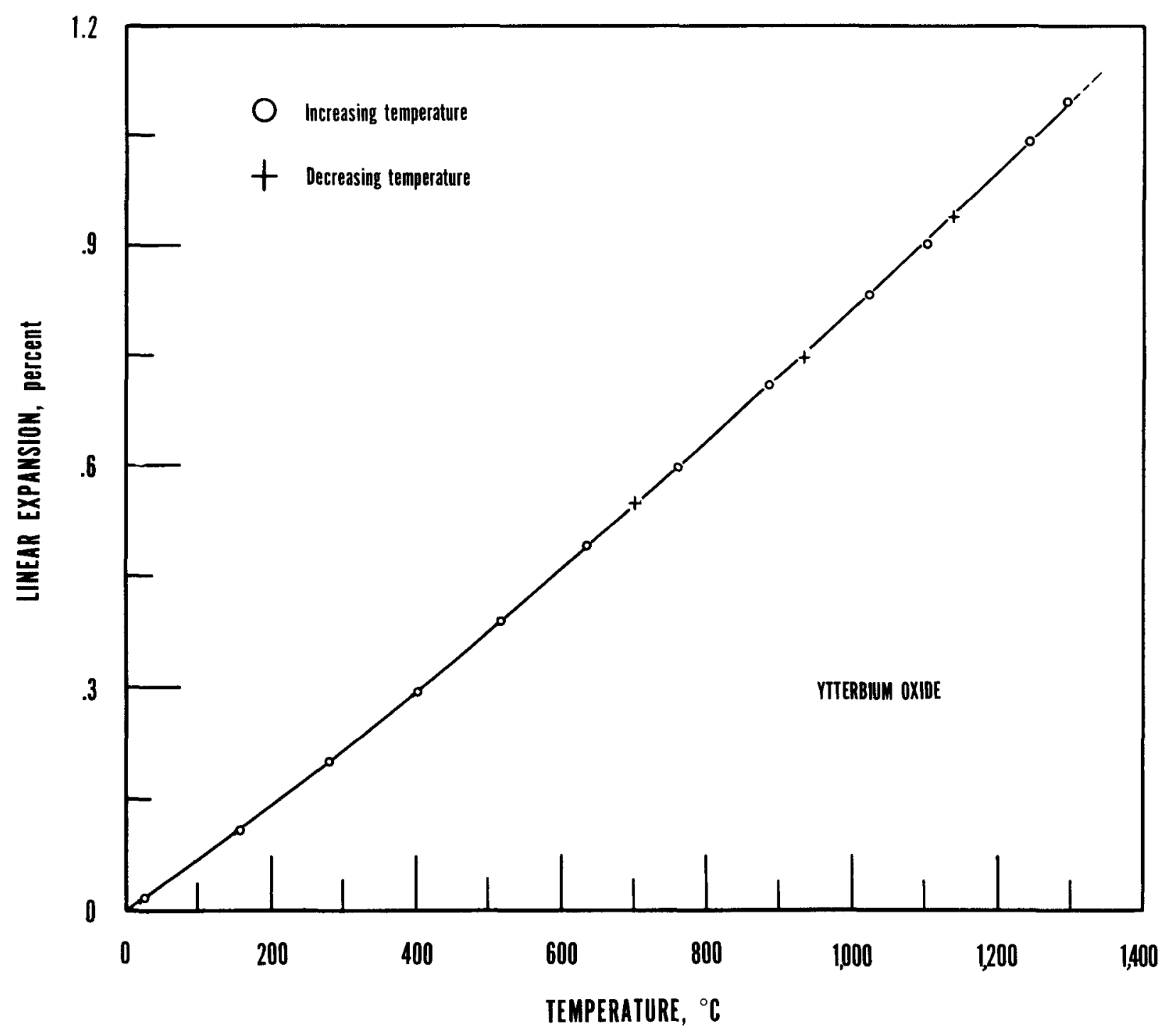

FIGURE 17. - Thermal Expansion of Ytterbium Sesquioxide. 
TABLE 26. - Powder X-ray diffraction data for ytterbium oxide at $25^{\circ} \mathrm{C} . \mathrm{I}^{\mathrm{I}}$

\begin{tabular}{|c|c|c|c|c|c|c|c|c|}
\hline hk1 & $\underset{A}{d-s p a c i n g,}$ & $\frac{I}{I_{100}} \times 100$ & $a, A$ & hk 1 & $\underset{A}{d-s p a c i n g}$ & $\frac{I}{I_{100}}$ & $\times 100$ & $a, A$ \\
\hline$\overline{211}$ & 4.25 & 17 & 10.41 & 921 & 1.124 & & 3 & 10.423 \\
\hline 222 & 3.004 & 100 & 10.408 & 930 & 1.099 & & 3 & 10.424 \\
\hline 320 & 2.881 & 2 & 10.392 & 932 & 1.0757 & & 4 & 10.4293 \\
\hline 321 & 2.783 & 3 & 10.415 & 840 & 1.0640 & & 7 & 10.4250 \\
\hline 400 & 2.603 & 42 & 10.413 & 941 & 1.0535 & & 4 & 10.4291 \\
\hline 411 & 2.455 & 8 & 10.414 & $10 \cdot 0 \cdot 0$ & 1.0429 & & 2 & 10.4292 \\
\hline 331 & 2.390 & 3 & 10.418 & $10 \cdot 1 \cdot 1$ & 1.0326 & & 1 & 10.4290 \\
\hline 420 & 2.329 & 2 & 10.416 & $10 \cdot 2 \cdot 0$ & 1.0227 & & 5 & 10.4300 \\
\hline 332 & 2.221 & 6 & 10.416 & 950 & 1.0130 & & 7 & 10.4295 \\
\hline 422 & 2.126 & 1 & 10.417 & $10 \cdot 2 \cdot 2$ & 1.0036 & & 4 & 10.4297 \\
\hline 510 & 2.043 & 13 & 10.418 & $10 \cdot 3 \cdot 1$ & 0.9945 & & 4 & 10.4300 \\
\hline 521 & 1.902 & 4 & 10.419 & 871 & .9769 & & 4 & 10.4300 \\
\hline 440 & 1.840 & 47 & 10.411 & $10 \cdot 4 \cdot 0$ & .9684 & & 2 & 10.4299 \\
\hline 530 & 1.788 & 4 & 10.428 & $10 \cdot 3 \cdot 3$ & .9602 & & 3 & 10.4302 \\
\hline 600 & 1.738 & 2 & 10.426 & $10 \cdot 4 \cdot 2$ & .9521 & & 3 & 10.4298 \\
\hline 611 & 1.690 & 8 & 10.420 & $11 \cdot 1 \cdot 0$ & .9443 & & 3 & 10.4305 \\
\hline 620 & 1.648 & 2 & 10.424 & $11 \cdot 2 \cdot 1$ & .9292 & & 2 & 10.4301 \\
\hline 541 & 1.608 & 6 & 10.424 & 880 & .9219 & & 1 & 10.4304 \\
\hline 622 & 1.570 & 37 & 10.412 & $10 \cdot 4 \cdot 4$ & .9077 & & 3 & 10.4305 \\
\hline 631 & 1.535 & 9 & 10.414 & $11 \cdot 3 \cdot 2$ & .9011 & & 1 & 10.4308 \\
\hline 444 & 1.503 & 10 & 10.412 & $10 \cdot 6 \cdot 0$ & .8944 & & 2 & 10.4309 \\
\hline 710 & 1.473 & 3 & 10.415 & $11 \cdot 4 \cdot 1$ & .8881 & & 4 & 10.4329 \\
\hline 640 & 1.444 & 2 & 10.414 & $10 \cdot 6 \cdot 2$ & .8816 & & 1 & 10.4308 \\
\hline 721 & 1.417 & 5 & 10.415 & 965 & .8754 & & 3 & 10.4311 \\
\hline 642 & 1.392 & 2 & 10.416 & $12 \cdot 0 \cdot 0$ & .8693 & & 4 & 10.4315 \\
\hline 732 & 1.323 & 4 & 10.418 & $12 \cdot 1 \cdot 1$ & .8633 & & 4 & 10.4315 \\
\hline 800 & 1.302 & 5 & 10.418 & $12 \cdot 2 \cdot 0$ & .8575 & & 4 & 10.4318 \\
\hline 811 & 1.283 & 5 & 10.421 & $11 \cdot 5 \cdot 2$ & .8517 & & 2 & 10.4314 \\
\hline 820 & 1.263 & 3 & 10.419 & $12 \cdot 2 \cdot 2$ & .8461 & & 3 & 10.4318 \\
\hline 653 & 1.245 & 3 & 10.420 & $12 \cdot 3 \cdot 1$ & .8406 & & 3 & 10.4319 \\
\hline 822 & 1.228 & 2 & 10.422 & $11 \cdot 6 \cdot 1$ & .8299 & & 3 & 10.4319 \\
\hline 831 & 1.216 & 5 & 10.422 & $12 \cdot 4 \cdot 0$ & .8248 & & 3 & 10.4324 \\
\hline 662 & 1.196 & 10 & 10.422 & $12 \cdot 3 \cdot 3$ & .8196 & & 2 & 10.4320 \\
\hline 840 & 1.165 & 7 & 10.423 & $12 \cdot 4 \cdot 2$ & .8146 & & 6 & 10.4324 \\
\hline 910 & 1.151 & $i$ & 10.422 & $11 \cdot 6 \cdot 3$ & .8097 & & 2 & 10.4323 \\
\hline 842 & 1.137 & 2 & 10.424 & $\begin{array}{l}10 \cdot 8 \cdot 2 \\
13 \cdot 1 \cdot 0\end{array}$ & $\begin{array}{l}.8049 \\
.8004\end{array}$ & & $\begin{array}{l}4 \\
2\end{array}$ & $\begin{array}{l}10.4326 \\
10.4353\end{array}$ \\
\hline
\end{tabular}

${ }^{1}$ Fired at $1,230^{\circ} \mathrm{C}$. for 24 hours.

\section{Lutetium Oxide $\left(\mathrm{Lu}_{2} \mathrm{O}_{3}\right)$}

Sample: Lutetium sesquioxide, supplied by Lindsay Chemica1 Co., West Chicago, II1. (their code 1505), was stated to be 99.9 percent $\mathrm{Lu}_{2} \mathrm{O}_{3}$ in total rare-earth content. Optical spectrographic analyses (see table 2) indicated that the major non-rare-earth impurities were calcium, magnesium, and silicon. 
Sample Preparation: The sample was sintered at $1,200^{\circ} \mathrm{C}$. for 24 hours, packed into an alumina sample holder, sintered at $1,250^{\circ} \mathrm{C}$. for 12 hours, cooled to $300^{\circ} \mathrm{C}$. and placed in a vacuum desiccator for storage.

Method: The 222 and 10.6.2 lines were used for furnace alinement. Thermal expansion was determined from the 844, 10.2.2 and 10.6.2 lines; maximum deviation between values from all three lines was less than \pm 2 percent above $500^{\circ} \mathrm{C}$.

\section{Results: See table 27 and figure 18.}

Discussion: Lutetium sesquioxide is cubic (rare-earth oxide type $C$ ), the lattice parameter is $10.391 \pm 0.005 \mathrm{~A}$ at an unspecified temperature (20). Curtis (5) listed the stronger diffraction lines of $\mathrm{Lu}_{2} \mathrm{O}_{3}$, and a more extensive tabulation by the authors is given in table 28 . No phase inversion was observed over the temperature range covered $\left(25^{\circ}\right.$ to $\left.1,300^{\circ} \mathrm{C}.\right)$.

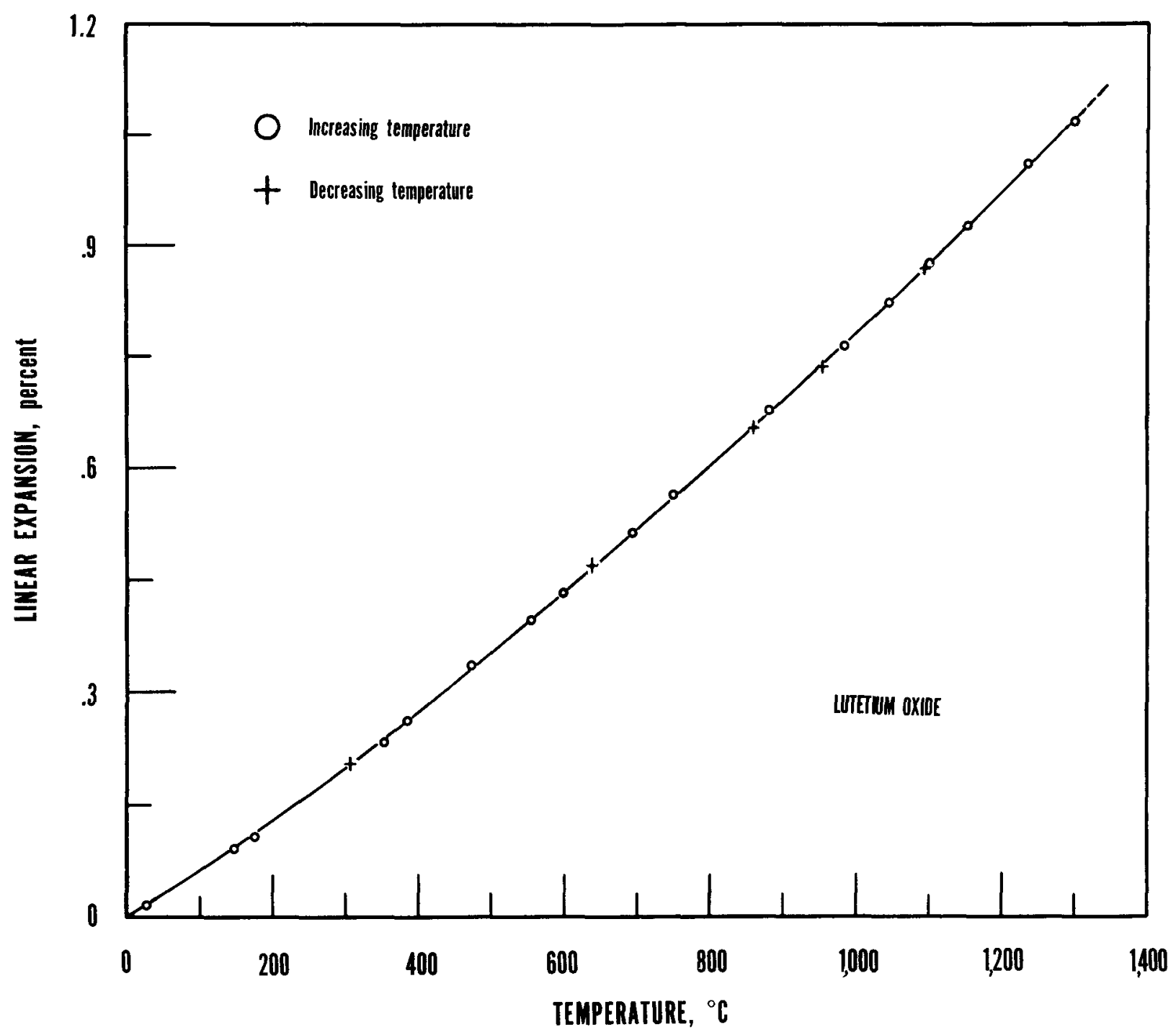

FIGURE 18. - Thermal Expansion of Lutetium Sesquioxide. 
TABLE 27. - Thermal expansion of lutetium oxide

\begin{tabular}{|c|c|c|c|}
\hline $\begin{array}{c}\text { Temperature, } \\
\circ \mathrm{C} .\end{array}$ & $\begin{array}{l}\text { Unit cell } \\
\text { parameter, A }\end{array}$ & $\begin{array}{c}\text { Linear expansion, } \\
\text { percent }\end{array}$ & $\begin{array}{l}\text { Linear expansion } \\
\text { coefficient }\left(\times 10^{6}\right)\end{array}$ \\
\hline $\begin{array}{r}0 \ldots \ldots \ldots \\
27 \ldots \ldots \ldots \\
148 \ldots \ldots \ldots \\
175 \ldots \ldots \ldots \\
352 \ldots \ldots \ldots \\
385 \ldots \ldots \ldots \\
472 \ldots \ldots \ldots \\
555 \ldots \ldots \\
599 \ldots \ldots \\
695 \ldots \ldots \\
750 \ldots \ldots \\
860 \ldots \ldots \\
880 \ldots \ldots \\
984 \ldots \ldots \\
1,045 \ldots \ldots \ldots \\
1,100 \ldots \ldots \\
1,152 \ldots \ldots \ldots \\
1,235 \ldots \ldots \\
1,300 \ldots \ldots \\
1,095 \ldots \ldots \\
954 \ldots \ldots \\
860 \ldots \ldots \\
640 \ldots \ldots \\
305 \ldots \ldots \ldots \\
\ldots \ldots \\
\ldots\end{array}$ & $\begin{array}{l}10.3847 \\
10.3864 \\
10.3943 \\
10.3965 \\
10.4409 \\
10.4119 \\
10.4195 \\
10.4259 \\
10.4298 \\
10.4382 \\
10.4435 \\
10.4531 \\
10.4554 \\
10.4642 \\
10.4704 \\
10.4759 \\
10.4811 \\
10.4898 \\
10.4957 \\
10.4754 \\
10.4614 \\
10.4528 \\
10.4335 \\
10.4059\end{array}$ & $\begin{array}{l}0.00 \\
.016 \\
.092 \\
.107 \\
.235 \\
.262 \\
.335 \\
.397 \\
.434 \\
.515 \\
.566 \\
.659 \\
.681 \\
.766 \\
.825 \\
.878 \\
.928 \\
1.012 \\
1.068 \\
.873 \\
.739 \\
.656 \\
.470 \\
.204\end{array}$ & $\begin{array}{l}5.9 \\
6.2 \\
6.1 \\
6.6 \\
6.8 \\
7.0 \\
7.1 \\
7.2 \\
7.4 \\
7.5 \\
7.6 \\
7.7 \\
7.7 \\
7.8 \\
7.9 \\
8.0 \\
8.1 \\
8.2 \\
7.9 \\
7.7 \\
7.6 \\
7.3 \\
6.6\end{array}$ \\
\hline
\end{tabular}


TABLE 28. - Powder X-ray diffraction data for

lutetium oxide at $25^{\circ} \mathrm{C} .1$

\begin{tabular}{|c|c|c|c|c|c|c|c|c|}
\hline hk 1 & $\begin{array}{c}\text { d-spacing, } \\
\text { A }\end{array}$ & $\frac{I}{I_{100}} \times 100$ & $a, A$ & hk 1 & $\begin{array}{c}\mathrm{d}-\mathrm{spacing} \\
\mathrm{A}\end{array}$ & $\frac{I}{I_{100}}$ & $\times 100$ & $a, A$ \\
\hline 211 & 4.21 & 9 & 10.31 & 842 & 1.133 & & 2 & 10.382 \\
\hline 222 & 2.984 & 100 & 10.335 & 921 & 1.120 & & 4 & 10.383 \\
\hline 321 & 2.764 & 3 & 10.342 & 851 & 1.095 & & 4 & 10.385 \\
\hline 400 & 2.595 & 40 & 10.378 & 932 & 1.0711 & & 3 & 10.3846 \\
\hline 411 & 2.440 & 5 & 10.352 & 844 & 1.0599 & & 6 & 10.3853 \\
\hline 331 & 2.376 & 2 & 10.356 & 941 & 1.0493 & & 3 & 10.3865 \\
\hline 332 & 2.208 & 7 & 10.355 & $10 \cdot 0 \cdot 0$ & 1.0387 & & 2 & 10.3875 \\
\hline 431 & 2.032 & 11 & 10.359 & $10 \cdot 2 \cdot 0$ & 1.0186 & & 5 & 10.3893 \\
\hline 440 & 1.832 & 30 & 10.363 & 943 & 1.0089 & & 1 & 10.3918 \\
\hline 433 & 1.778 & 4 & 10.365 & $10 \cdot 2 \cdot 2$ & 0.9996 & & 6 & 10.3884 \\
\hline 611 & 1.681 & 5 & 10.360 & $10 \cdot 3 \cdot 1$ & .9905 & & 4 & 10.3919 \\
\hline 541 & 1.600 & 4 & 10.369 & 871 & .9730 & & 3 & 10.3919 \\
\hline 622 & 1.563 & 22 & 10.369 & $10 \cdot 4 \cdot 0$ & .9647 & & 4 & 10.3899 \\
\hline 631 & 1.529 & 5 & 10.372 & $10 \cdot 3 \cdot 3$ & .9565 & & 2 & 10.3876 \\
\hline 444 & 1.497 & 6 & 10.372 & $10 \cdot 4 \cdot 2$ & .9485 & & 4 & 10.3860 \\
\hline 543 & 1.467 & 5 & 10.372 & 954 & .9407 & & 3 & 10.3944 \\
\hline 640 & 1.439 & 2 & 10.373 & $11 \cdot 2 \cdot 1$ & .9257 & & 3 & 10.3862 \\
\hline 721 & 1.412 & 5 & 10.373 & 880 & .9184 & & 1 & 10.3876 \\
\hline 642 & 1.386 & 3 & 10.373 & $10 \cdot 4 \cdot 4$ & .9045 & & 2 & 10.3922 \\
\hline 732 & 1.318 & 4 & 10.378 & $11 \cdot 3 \cdot 2$ & .8977 & & 2 & 10.3954 \\
\hline 800 & 1.298 & 5 & 10.384 & $10 \cdot 6 \cdot 0$ & .8911 & & 1 & 10.3907 \\
\hline 811 & 1.277 & 6 & 10.378 & $11 \cdot 4 \cdot 1$ & .8846 & & 2 & 10.3944 \\
\hline 820 & 1.259 & 3 & 10.379 & $10 \cdot 6 \cdot 2$ & .8783 & & 5 & 10.3897 \\
\hline 653 & 1.241 & 3 & 10.380 & 965 & .8720 & & 1 & 10.3944 \\
\hline 822 & 1.223 & 3 & 10.378 & $12 \cdot 0 \cdot 0$ & .8661 & & 2 & 10.3926 \\
\hline 831 & 1.207 & 2 & 10.381 & $12 \cdot 1 \cdot 1$ & .8600 & & 4 & 10.3895 \\
\hline 662 & 1.191 & 10 & 10.380 & $12 \cdot 2 \cdot 0$ & .8543 & & 3 & 10.3964 \\
\hline 840 & 1.161 & 8 & 10.381 & $11 \cdot 5 \cdot 2$ & .8486 & & 2 & 10.3955 \\
\hline 833 & 1.147 & 2 & 10.383 & $12 \cdot 2 \cdot 2$ & .8429 & & 3 & 10.3934 \\
\hline
\end{tabular}

${ }^{2}$ Fired at $1,330^{\circ} \mathrm{C}$. for 24 hours. 


\section{B IBLIOGRAPHY}

1. BLUM, S. L., AND MAGUIRE, E. A. Differential Thermal Analysis of Some Yttrium and Lanthanon Compounds. Ceram. Bul1. vo1. 39, 1960, pp. 310-312.

2. BRAUER, VON G., AND GRADINGER, H. Über heterotype Mischphasen bei Seltenerdoxyden. Ztschr. anorg. u. allgem. Chemie, vol. 276, 1954, pp. 209-226.

3. CAMPBELL, W. J., STECURA, S., AND GRAIN, C. High Temperature Furnaces for X-Ray diffractometers. Bureau of Mines Rept. of Investigations No. 5738, $1961,30 \mathrm{pp}$.

4. CURTIS, C. E. Properties of Yttrium Oxide Ceramics. Jour. Am. Ceram. Soc., vol. 40, 1957, pp. 274- 278 .

5. . Further Studies in the Sintering of the Rare-Earth Oxides. Preprint of paper presented to Amer. Ceram. Soc., Chicago, I11., May 1959.

6. CURTIS, C. E., AND JOHNSON, J.R. Ceramic Properties of Samarium Oxide and Gadolinium Oxide; X-Ray Studies of Other Rare-Earth Oxides and Some Compounds. Jour. Am. Ceram. Soc., vol. 40, 1957, pp. 15-19.

7. CURTIS, E. C., AND THARP, A. G. Ceramic Properties of Europium Oxide. Jour. Am. Ceram. Soc., vo1. 42, 1959, pp. 151-156.

8. Douglass, R. M. Crystallographic Data 111, Neodymium Sesquioxide, Form A. Ana1. Chem., vo1. 28, 1956, pp. 551-552.

9. DOUGLASS, R. M., AND STARITZKY, E. Crystallographic Data 112, Samarium Sesquioxide, Form B. Ana1. Chem., vo1. 28, 1956, p. 552.

10. GUENTERT, O. J., AND MOZZI, R. L. The Monoclinic Modification of Gadolinium Sesquioxide. Acta Cryst., vo1. 11, 1958, p. 746.

11. HONIG, J. M. Literature Review on Properties of Praseodymium and Cerium Oxides. Dept. of Chemistry, Purdue University, AD 148090, AFOSR-TN-58-57, 1958, 49 pp.

12. LOHBERG, K. Über die C-Modification der Sesquioxide of Neodymium and Lanthanum. Ztschr. physik Chem,, vo1. 28B, 1935, pp. 402-407.

13. MAUER, F. A., AND BOLZ, L. H. Measurement of Thermal Expansion of Cermet Components by High Temperature X-Ray Diffraction. Wright Air Development Center Tech. Report 55-473, 1955, 57 pp.; also 55-473, supplement 1, 1957,47 Pp.

14. PLOETZ, G. L., AND Krystyniak, C. W. Sintering Characteristics of Rare Earth Oxides. Knolls Atomic Power Laboratory, Schenectady, N. Y. KAPL- 1067, 1956, 17 pp. 
15. PLOETZ, G. L., KRYSTYNIAK, C. W., AND DUMAS, H. E. Thermal Expansion of Four Rare Earth Oxides. Knolls Atomic Power Laboratory, Schenectady, N.Y. KAPI-M- GLP- 1, 1957, 8 pP.

16. QUILL, L. L. Researches in Rare Earth Chemistry. Record Chem. Progr., vol. 11,1950 , pp. 151-163.

17. STARITZKY, E. Crystallographic Data 144. Yttrium Sesquioxide, 145. Dysprosium Sesquioxide. 146. Erbium Sesquioxide, 147. Ytterbium Sesquioxide. Ana1. Chem. vo1. 28, 1956, pp. 2023-2024.

18. STUTZMAN, R. H., SALVAGGI, J. R., AND KIRCHNER, H. P. An Investigation of the Theoretical and Practical Aspects of the Thermal Expansion of Ceramic Materia1s-- Literature Survey. Cornel1 Aeronautical Laboratory, Inc., Buffalo, N.Y. AD 220685, vo1. 1, 1959, 157 pp.

19. SWANSON, H. E., AND OTHERS. Standard X-Ray Diffraction Powder Patterns : Nat. Bureau of Standards Cir. 539, vo1. 1-9, 1953-60.

20. TEMPLETON, D. H., AND DAUBEN, C. H. Lattice Parameters of Some Rare Earth Compounds and a Set of Crystal Radi1. Jour. Am. Chem. Soc., vo1. 76, 1954, pp. 5237-5239. 